RICARDO CARBONARI CHEBEL

Association between body condition score change during the dry-period and postpartum health and performance

São Paulo

2018 
RICARDO CARBONARI CHEBEL

Association between body condition score change during the dry-period and postpartum health and performance

Tese apresentada ao Programa de PósGraduação em Reprodução Animal da Faculdade de Medicina Veterinária e Zootecnia da Universidade de São Paulo para obtenção do título de Doutor em Ciências.

Departamento:

Reprodução Animal

Área de concentração:

Reprodução Animal

Orientador:

Prof. Dr. Pietro Sampaio Baruselli

São Paulo 
Total or partial reproduction of this work is permitted for academic purposes with the proper attribution of authorship and ownership of the rights.

\section{DADOS INTERNACIONAIS DE CATALOGAÇÃO NA PUBLICAÇÃO}

(Biblioteca Virginie Buff D’Ápice da Faculdade de Medicina Veterinária e Zootecnia da Universidade de São Paulo)

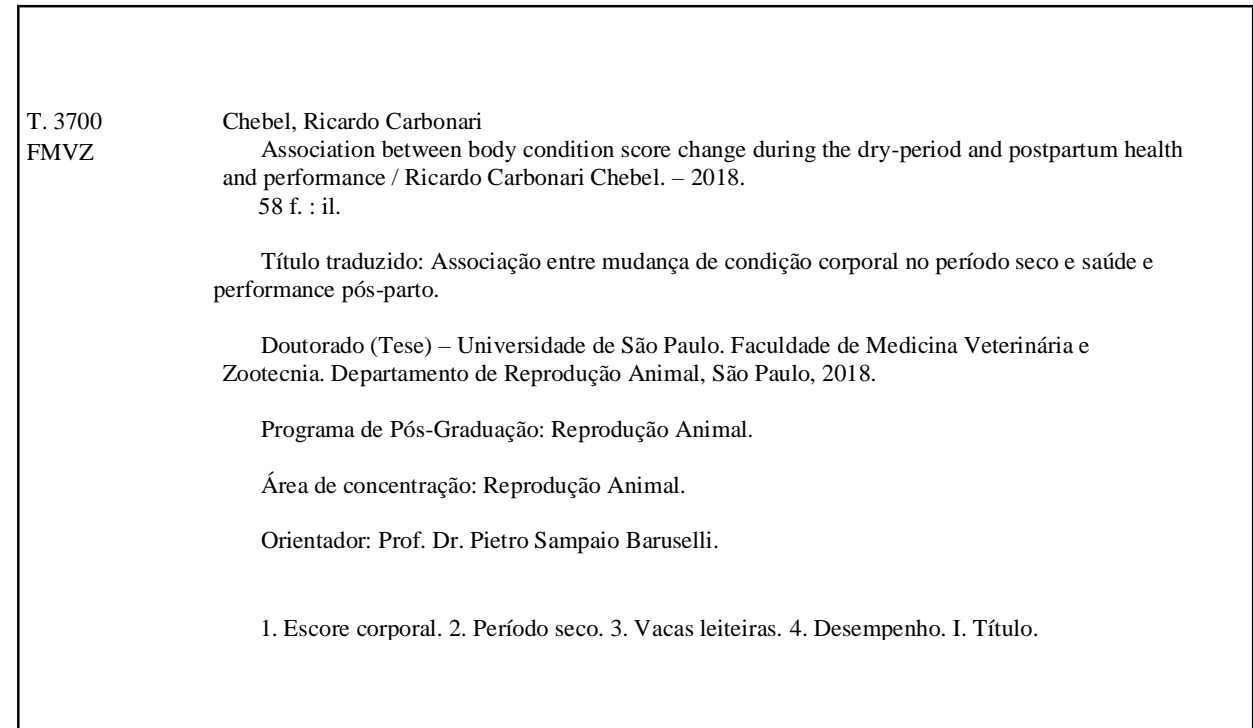

Ficha catalográfica elaborada pela bibliotecária Maria Aparecida Laet, CRB 5673-8, da FMVZ/USP. 
IImo(a). Sr(a).

Responsável: Pietro Baruselli

Área: 0

Equipe envolvida: Ricardo Carbonari Chebel - executor (--); Pietro Baruselli (orientador)

Título do projeto: "Consequências da perda de peso durante o final da gestação de bovinos sobre parâmetros imunológicos e metabólicos e performance reprodutiva da vaca".

\section{Parecer Consubstanciado da CEUA FMVZ/USP}

Este experimento é retrospectivo com base em dados gerados por experimentos conduzidos na Universidade de Minnesota, EUA, entre os anos 2009 e 2013. Os dados contínuos serão analisados por análise de variância usando o procedimento GLM do SAS. Os dados contínuos com medições repetidas serão analisados por ANOVA para medidas repetidas, utilizando o procedimento MIXED do SAS. Dados dicotômicos serão analisados pelo teste do quiquadrado, utilizando o procedimento FREQ do SAS.

A Comissão de Ética no Uso de Animais da Faculdade de Medicina Veterinária e Zootecnia da Universidade de São Paulo, na reunião de 23/05/2018, ANALISOU e APROVOU o protocolo de estudo acima referenciado. A partir desta data, é dever do pesquisador: 1. Comunicar toda e qualquer alteração do protocolo.

2. Comunicar imediatamente ao Comitê qualquer evento adverso ocorrido durante o desenvolvimento do protocolo.

3. Os dados individuais de todas as etapas da pesquisa devem ser mantidos em local seguro por 5 anos para possível auditoria dos órgãos competentes.

4. Relatórios parciais de andamento deverão ser enviados anualmente à CEUA até a conclusão do protocolo.

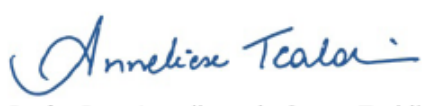

Profa. Dra. Anneliese de Souza Trald Presidente da Comissão de Ética no Uso de Animais Faculdade de Medicina Veterinária e Zootecnia da Universidade de São Paulo

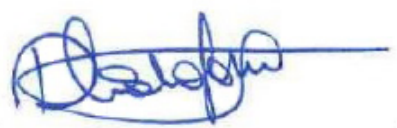

Roseli da Costa Gomes Secretária

Faculdade de Medicina Veterinária e Zootecnia da Universidade 


\section{CERTIFIED}

We certify that the Research "Weight loss effects during late pregnancy cattle on the immunological and metabolic parameters and reproductive performance of the cow", protocol number CEUAx 5220050214 (ID 000924), under the responsibility Pietro Baruselli, agree with Ethical Principles in Animal Research adopted by Ethic Committee in the Use of Animals of School of Veterinary Medicine and Animal Science (University of São Paulo), and was approved in the meeting of day May 23, 2018.

Certificamos que o protocolo do Projeto de Pesquisa intitulado "Consequências da perda de peso durante o final da gestação de bovinos sobre parâmetros imunológicos e metabólicos e performance reprodutiva da vaca", protocolado sob o CEUAx nำ 5220050214, sob a responsabilidade de Pietro Baruselli, está de acordo com os princípios éticos de experimentação animal da Comissão de Ética no Uso de Animais da Faculdade de Medicina Veterinária e Zootecnia da Universidade de São Paulo, e foi aprovado na reunião de 23 de maio de 2018.

$$
\text { Onneliese Teala. }
$$

Profa. Dra. Anneliese de Souza Traldi Presidente da Comissão de Ética no Uso de Animais Faculdade de Medicina Veterinária e Zootecnia da Universidade de São Paulo

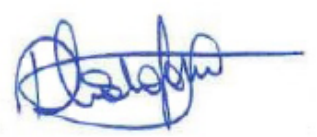

Roseli da Costa Gomes Secretária

Faculdade de Medicina Veterinária e Zootecnia da Universidade de São Paulo 


\section{FOLHA DE AVALIAÇÃO}

Nome: CHEBEL, Ricardo Carbonari

Título: Association between body condition score change during the dry-period and postpartum health and performance

Tese apresentada ao Programa de PósGraduação em Reprodução Animal da Faculdade de Medicina Veterinária e Zootecnia da Universidade de São Paulo para a obtenção do título de Doutor em Ciências.

Aprovado em:

Banca Examinadora

Prof. Dr. Instituição:

Julgamento: Assinatura:

Prof. Dr. Instituição:

Julgamento: Assinatura:

Prof. Dr. Instituição:

Julgamento: Assinatura:

Prof. Dr. Instituição:

Julgamento: Assinatura:

Prof. Dr. Instituição:

Julgamento: Assinatura: 


\section{Acknowledgment}

Dedico este trabalho a Eliana Carbonari, Rita Fernandes e Mariana Pelissari que me incentivaram a encarar os desafios mais difíceis da minha vida. Espero que a minha gratidão seja reconhecida através das minhas atitudes. Faço uma homenagem póstuma a Roberto Jorge Chebel, a quem devo o amor pela medicina veterinária, o espirito inquisitivo, e a coragem de me aventurar em terras distantes. Agradeço, de maneira póstuma, a Wylma Carbonari que me acolheu como um filho e até o fim me encorajou para que me tornasse um homem melhor. Agradeço a José Eduardo Santos, Klibs Galvão, Gláucio Lopes, Luís Mendonça e Todd Bilby que se tornaram irmãos nesta caminhada árdua, mas inexplicavelmente gratificante. Finalmente, não posso eximir-me de agradecer profundamente ao Prof. Dr. Pietro Sampaio Baruselli pela oportunidade conferida, pelos ensinamentos, e pela amizade.

Digo que os anos que passaram me fizeram mais calejado, mas também me ensinaram a aceitar de maneira mais calma a mim mesmo e as pessoas que me cercam. Longe de ser perfeito, sinto prazer em evoluir nas mais diversas áreas da vida, mesmo com os constantes retrocessos. Meu compromisso sempre será buscar conhecimento que seja relevante à comunidade científica e, principalmente, aos produtores e à sociedade que servimos. Espero que meus colegas e alunos me alertem quando este objetivo já não for mais minha prioridade evidente, para que eu possa me retirar com dignidade. Não quero apenas criar hipóteses para poder prová-las, quero que a minha relação com produtores, colegas e alunos me incentive a criar e responder hipóteses de fato relevantes. Prefiro publicar algo que esteja errado do que publicar algo que não tem importância. 


\section{RESUMO}

CHEBEL, R. C. Associação entre mudança de condição corporal no período seco e saúde e performance pós-parto. 2018. 58 f. Tese (Doutorado) - Faculdade de Medicina Veterinária e Zootecnia, Universidade de São Paulo, São Paulo, 2018.

A transição entre os períodos seco e lactante é fundamental para a saúde e performance de vacas leiteiras. Comumente em propriedades rurais, as condições de manejo de animais no período de transição são inapropriadas (i.e. estresse calórico, disponibilidade de alimento e água limitada), aumentando o risco de doenças peri-parto e redução na produção de leite. O escore de condição corporal (ECC) determina subjetivamente a quantidade de tecido adiposo subcutâneo de um animal, enquanto a mudança de ECC indica subjetivamente o balanço energético do mesmo, já que uma mudança de 0,25 unidade no ECC representa uma mudança de aproximadamente $18 \mathrm{~kg}$ no peso corporal. Os objetivos do presente estudo foram determinar a associação entre a alteração do escore de condição corporal durante o período seco ( $\mathbf{E E C C})$ e a saúde pós-parto e o desempenho reprodutivo e produtivo de vacas holandesas. Dados de 16.104 lactações de 9.950 vacas de duas fazendas leiteiras localizadas no Vale de São Joaquim da Califórnia foram utilizados. Em cada fazenda, as vacas foram classificadas quanto ao ECC no momento da secagem e do parto pelos mesmos funcionários, que foram treinados por veterinários do Centro de Pesquisa e Ensino de Medicina Veterinária da Universidade da Califórnia em Davis. As vacas foram classificadas como tendo perda excessiva de ECC (ELBCS, $\triangle \mathrm{ECC} \leq-0,75 ; \mathrm{n}=1,604)$, perda moderada de ECC (MLBCS, $\triangle \mathrm{ECC}=-0,5$ a $-0,25$; $\mathrm{n}=6,430)$, sem alteração no $\mathrm{ECC}(\mathrm{NCBCS}, \triangle \mathrm{ECC}=0 ; \mathrm{n}=4.819)$, e ganho de ECC (GBCS, $\Delta \mathrm{ECC} \geq 0,25 ; \mathrm{n}=3.251)$. Os dados referentes à morbidade, mortalidade e ao desempenho reprodutivo e produtivo foram registrados até 305 dias pós-parto ou até que as vacas fossem secadas ou deixassem o rebanho. A perda de ECC durante o período seco foi associada com maior incidência de doença uterina e indigestão de alimentos. Além disso, a perda de ECC durante o período seco foi associada à maior probabilidade de tratamento com antimicrobianos, terapia anti-inflamatória e de suporte. A perda de ECC durante o período seco foi associada com a redução da probabilidade de prenhez após a primeira e segunda inseminações pós-parto. As vacas que ganharam ECC durante o período seco apresentaram maior produção de leite, gordura e proteína, e redução do escore linear de células somáticas na lactação subsequente. Os dados do presente estudo foram indicativos de que a perda de ECC durante o período seco é fator predisponente associado a distúrbios de saúde e redução do desempenho produtivo e reprodutivo de vacas Holandesas. 
Palavras-chave: Escore corporal. Período seco. Vacas leiteiras. Desempenho. 


\begin{abstract}
CHEBEL, R. C. Association between body condition score change during the dry-period and postpartum health and performance. 2018. $58 \mathrm{f}$. Tese (Doutorado) - Faculdade de Medicina Veterinária e Zootecnia, Universidade de São Paulo, São Paulo, 2018.

The transition between the dry and lactating periods is fundamental for the health and performance of dairy cows. Commonly on farms, animal management conditions in the transition period are inappropriate (i.e., heat stress, limited availability of food and water), increasing the risk of peri-partum diseases and reduced milk production. Body condition score (BCS) subjectively determines the amount of subcutaneous adipose tissue of an animal and the change in BCS subjectively estimates the energy balance of the animal, as a change in 0.25 unit in BCS represents a change in approximately $18 \mathrm{~kg}$ in body weight. The objectives of the current study were to determine the association between body condition score change during the dryperiod $(\mathbf{B C C S})$ and postpartum health and reproductive and productive performance of Holstein cows. Data from 16,104 lactations from 9,950 parous cows from two dairies located in the San Joaquin Valley of California were used. Within dairy, cows were scored for body condition (BCS) at dry-off and parturition by the same herdsmen, who were trained by veterinarians from the Veterinary Medicine Teaching and Research Center of the University of California Davis. Cows were classified as having excessive loss of BCS (ELBCS, $\triangle \mathrm{BCS} \leq-0.75 ; \mathrm{n}=1,604$ ), moderate loss of BCS (MLBCS, $\triangle \mathrm{BCS}=-0.5$ to $-0.25 ; \mathrm{n}=6,430$ ), no change in BCS (NCBCS, $\triangle \mathrm{BCS}=0 ; \mathrm{n}=4,819)$, and gained $\mathrm{BCS}(\mathrm{GBCS}, \triangle \mathrm{BCS} \geq 0.25 ; \mathrm{n}=3,251)$. Data regarding morbidity, mortality, and reproductive and productive performance were recorded until $305 \mathrm{~d}$ postpartum or until cows were dried-off or left the herd. Loss of BCS during the dry-period was associated with greater incidence of uterine disease and indigestion. Additionally, loss of BCS during the dry-period was associated with greater likelihood of treatment with antimicrobials, anti-inflammatory, and supportive therapy. Loss of BCS during the dry-period was associated with reduced likelihood of pregnancy after the first and second postpartum inseminations. Cows that gained BCS during the dry-period had greater yield of milk, fat, and protein and had reduced somatic cell linear score in the subsequent lactation. In the current study, loss of BCS during the dry-period was a predisposing factor associated with health disorders and reduced productive and reproductive performance in Holstein cows.
\end{abstract}

Keywords: Body condition score. Dry-period. Lactating dairy cow. Performance. 


\section{FIGURE LIST}

Figure 1 - Distribution of body condition score (BCS) at dry-off (A), BCS change during the dry-period (B), and BCS at calving (C) according to dairy, and mean $( \pm$ SEM) BCS at dry-off and BCS at calving according to change in BCS during the dryperiod $(\triangle \mathrm{BCS}$; panel D)

Figure 2 - Proportion of variation (\%) in body condition score (BCS) at dry-off (A) and BCS change during the dry-period (B) explained by independent variables retained in the multivariate model.

Figure 3 - Probability of cows gaining BCS during the dry-period (GBCS) according to BCS at dry-off based on the results of the multivariate logistic regression..........

Figure 4 - Survival analysis of the interval from parturition to removal from the herd according to body condition score change during the dry-period $(\triangle \mathrm{BCS})$ and parity

Figure 5 - Survival analysis of the interval from parturition to removal from the herd according to body condition score change during the dry-period ( $\triangle \mathrm{BCS})$ and length of the dry-period.

Figure 6 - Survival analysis of the interval from parturition to pregnancy according to body condition score change during the dry-period $(\triangle \mathrm{BCS})$ and dairy....

Figure 7 - Survival analysis of the interval from parturition to pregnancy according to body condition score change during the dry-period $(\triangle \mathrm{BCS})$ and parity

Figure 8 - Association between change in BCS during the dry-period $(\triangle \mathrm{BCS})$ and yield of milk (A) and protein (B) 
TABLE LIST

Table 1 - Final logistic regression model of factors associated with uterine diseases postpartum.

Table 2 - Final logistic regression model of factors associated with indigestion within $60 \mathrm{~d}$ postpartum

Table 3 - Final logistic regression model of factors associated with treatment with parenteral antimicrobial within $60 \mathrm{~d}$ postpartum.

Table 4 - Final logistic regression model of factors associated with treatment with parenteral anti-inflammatory within $60 \mathrm{~d}$ postpartum.....

Table 5 - Final logistic regression model of factors associated with supportive therapy within $60 \mathrm{~d}$ postpartum.

Table 6 - Final logistic regression model of factors associated with pregnancy at $67 \mathrm{~d}$ after first postpartum AI.

Table 7 - Final logistic regression model of factors associated with hazard of pregnancy up to 305 DIM 


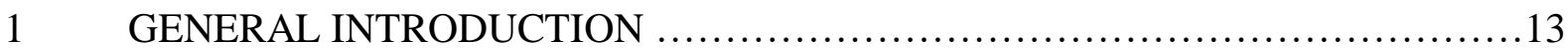

2 HYPOTHESIS ....................................................... 17

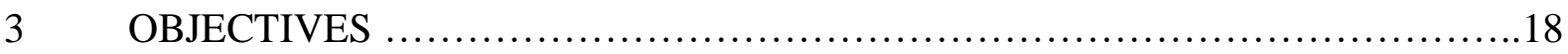

4 ASSOCIATION BETWEEN BODY CONDITION SCORE CHANGE DURING THE DRY-PERIOD AND POSTPARTUM HEALTH AND PERFORMANCE ......19

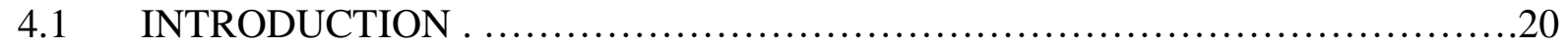

4.2 MATERIAL AND METHODS ................................................21

4.2.1 Animals, Facilities, and Management ........................................

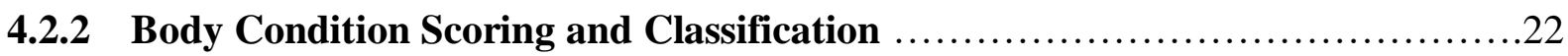

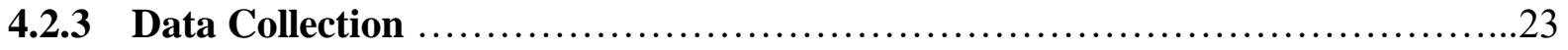

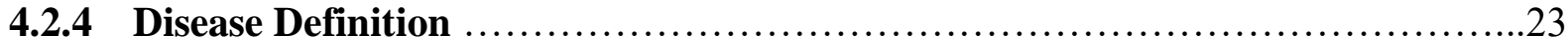

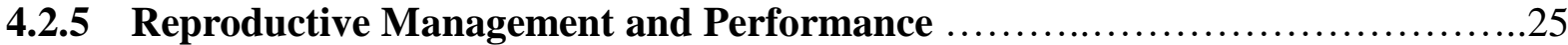

4.2.6 Milk Production Data Collection ...............................................25

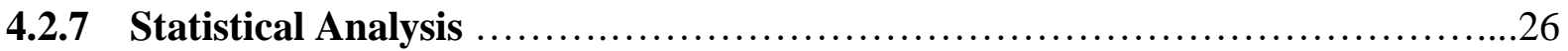

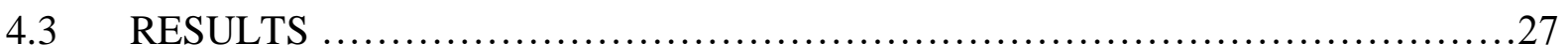

4.3.1 Association between $\Delta \mathrm{BCS}$ and Health Outcomes ............................

4.3.2 Association between $\triangle \mathrm{BCS}$ and Reproductive Parameters $\ldots \ldots \ldots \ldots \ldots \ldots \ldots \ldots \ldots$

4.3.3 Association between $\triangle \mathrm{BCS}$ and Productive Parameters .....................44

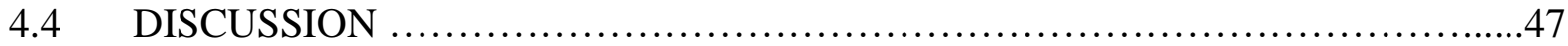

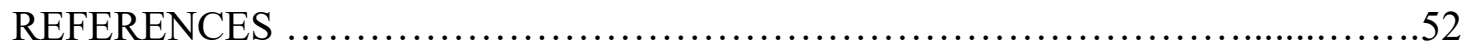

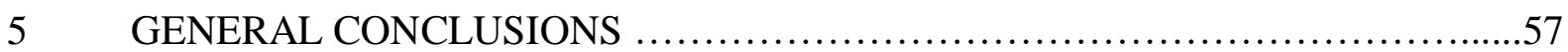

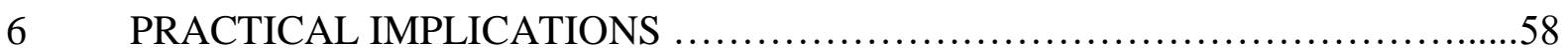




\section{GENERAL INTRODUCTION}

The period from three weeks before to three weeks after parturition in dairy cows, also known as the transition period, is characterized by significant changes in hormonal profile, feed intake, nutrient requirements, metabolism, and energy balance. These changes are known to dramatically affect immune function and, at times, health of dairy cows.

Peripartum hormonal changes and immune function: In the last week of gestation, concentrations of progesterone decrease as concentrations of cortisol, estradiol, prostaglandin $\mathrm{F}_{2 \alpha}$, and prolactin increase (STEVENSON, 2007). These changes are important for onset of colostrum production and preparation for parturition. Cortisol is the key hormone that regulates the decrease in progesterone concentration and consequently the increase in estradiol and prostaglandin $\mathrm{F}_{2 \alpha}$ (AKERS, 2002). Cortisol is also known to suppress immune response because it down regulates the neutrophil expression of L-selectin and CD18, adhesion molecules involved in the trafficking of neutrophils from the endothelium to the site of infection (BURTON and KEHRLI, 1995; BURTON et al., 1995; BURTON et al., 2005). Cortisol is frequently used as an indicator of stress, since many studies have demonstrated a correlation between adverse conditions (e.g. transport) and cortisol concentrations (NANDA; DOBSON; WARD, 1990). Therefore, conditions during the prepartum period that increase stress are expected to increase cortisol concentrations and consequently further suppress immune function of peripartum cows.

Homeorhectic adaptations during the peripartum period and immune function: At the same time that dramatic hormonal changes are occurring, feed intake in the last $14 \mathrm{~d}$ before parturition decreases by approximately 50\%, reaching its nadir on the day before parturition (GRUMMER; MASHEK; HAYIRLI, 2004). Although feed intake starts to increase immediately after parturition, it is not sufficient to meet nutrient requirements for the rapidly increasing milk yield. Thus, cows suffer from negative energy balance for up to 8 to 12 weeks after parturition and must utilize body energy reserves to meet nutrient requirements for milk production. Therefore, during the transition period cows go from a state of homeostasis to a state of homeorhesis, "orchestrated or coordinated changes in metabolism of body tissues necessary to support a dominant physiological state (BAUMAN and CURRIE, 1980)." For

peripartum cows, increasing milk production is the dominant physiological state as the utilization of nutrients by the mammary gland of high producing dairy cows exceeds that of the 
rest of the body (BAUMAN, 2000). Some of the homeorhectic changes observed in the peripartum dairy cows are discussed below.

Before the decrease in feed intake prepartum starts, cows have low circulating concentrations of growth hormone $(\mathrm{GH})$ and high circulating concentrations of insulin and insulin-like growth factor-I (IGF-I). Once feed intake starts to decrease and negative energy balance occurs, GH concentration increases and insulin and IGF-I concentrations decrease indicating a decoupling of the somatotropic-IGF-I axis because the liver, under the influence of GH, is the main source of circulating IGF-I (RHOADS et al., 2004; LUCY, 2008). This occurs because during negative energy balance the expression of GH receptor (GHR), particularly GHR1 $\alpha$, is decreased (MCCARTHY et al., 2009). As cows return to positive energy balance hepatic expression of GHR $1 \alpha$ increases and hepatic IGF-I production starts to increase (LUCY, 2008).

Insulin-like growth factor-I is a fundamental factor that stimulates growth, differentiation, and functionality of several different cell types. For example, IGF-I is likely to affect innate immunity of peripartum cows because it regulates functionality (i.e. superoxide anion production, oxidative burst, and degranulation) of neutrophils, the primary defense line against infections (i.e. metritis and mastitis). Further, circulating concentrations of neutrophils and production of antibodies (i.e. IgG, IgM, and $\operatorname{IgA}$ ) are significantly increased in $\mathrm{GH}$ deficient humans and mice after GH-induced increase in concentrations of IGF-I (KIMATA and YOSHIDA, 1994; IBANEZ et al., 2005; SOHMIYA et al., 2005). Pigs that were treated with IGF-I stimulating compounds and were subjected to simultaneous weaning and transport had greater count and concentrations of neutrophil in the blood than non-treated pigs (KOJIMA et al., 2008). Thus, exacerbation of negative energy balance during the peripartum period is likely to affect innate and humoral immunity because cows would be exposed to extended periods of time with reduced IGF-I concentration.

Energy sources, liver function, and resulting metabolites: Ruminants have evolved to substitute glucose by volatile fatty acids (i.e. propionate, butirate, and acetate) and their derivative ketoacids as respiratory and lipogenic fuels (BAUMAN and CURRIE, 1980). Nonetheless, glucose remains essential for normal brain and liver function and for production of lactose in the mammary gland, being the latter the most important osmotic solute of milk production. During early lactation and negative energy balance, insulin-dependent uptake of glucose by tissues other than the mammary gland (i.e. muscle and adipose tissue) is reduced, in part because of increased GH concentrations, assuring that glucose is available for production of copious amounts of lactose and milk (BAUMAN, 2000; LUCY, 2008). In situations in which 
cows are exposed to severe and prolonged negative energy balance large amounts of body reserves (i.e. glycogen, lipids, and amino acids) are mobilized to provide the necessary substrate for milk production (GRUMMER; MASHEK; HAYIRLI, 2004). A consequence of extreme adipose tissue mobilization during the peripartum period is the increasing circulating concentration of non-esterified fatty acids (NEFA), which predisposes cows to hepatic lipidosis (GRUMMER; MASHEK; HAYIRLI, 2004). Consequently, concentrations of ketone bodies [e.g. beta-hydroxy butirate (BHBA)] may also increase because of compromised liver function and incomplete oxidation of NEFA (GRUMMER; MASHEK; HAYIRLI, 2004).

Association among feed intake, metabolites concentrations, immune function, and health peripartum: Amount of feed intake is inversely associated with plasma NEFA concentrations, and the latter affects neutrophil function (KLUCINSKI et al., 1988; RUKKWAMSUK; KRUIP; WENSING, 1999; HAMMON et al., 2006). HAMMON et al. (2006) demonstrated that cows that had reduced feed intake during the prepartum period had reduced neutrophil activity (phagocytosis and oxidative burst) during the peripartum and were more likely to develop metritis postpartum. This seems to be a consequence of the onset of colostrum/milk production and the simultaneous insufficient feed intake peripartum because cows that were mastectomized 4 months before parturition had greater expression of L-selectin prepartum, greater leukocyte count postpartum, and greater neutrophil killing activity postpartum than cows with intact mammary glands (KIMURA; GOFF; KEHRLI JR., 1999).

Compromised immune function due to altered metabolic status predisposes cows to infectious diseases (i.e. metritis, endometritis, and mastitis). Postpartum hepatic lipidosis has been associated with increased length of bacterial shedding from mastitic cows (HILL; REID; COLLINS, 1985) and prepartum increase in fat mobilization and serum lipoprotein metabolism resulted in increased risk of metritis and retained fetal membranes (KANEENE et al., 1997). In a recent large study, OSPINA et al. (2010) demonstrated that increasing prepartum and postpartum NEFA plasma concentrations were associated with increased risk of retained fetal membranes, metritis, clinical ketosis, and displacement of abomasum. Accentuated negative energy balance accompanied by increased BHBA plasma concentrations during early postpartum also has been associated with increased risk of peripartum diseases (ERB and GROHN, 1988; GROHN et al., 1989; CORREA; ERB; SCARLETT, 1993). For example, higher milk acetone concentrations were associated with increased risk of endometritis (REIST et al., 2003) and increasing BHBA plasma concentration was associated with increased risk of metritis and displacement of abomasum (OSPINA et al., 2010). 
Therefore, managerial inadequacies that increase and prolong the negative energy balance during the peripartum transform the normal homeorhetic changes into metabolic diseases (i.e. excessively elevated fat mobilization, hepatic lipidosis, and ketosis) further suppressing immune function of dairy cows and predisposing them to health disorders, and compromised productive, reproductive, and economic performances. 


\section{HYPOTHESIS}

The hypothesis of the current study was that $\triangle \mathrm{BCS}$ is associated with incidence of postpartum health disorders, yield of milk and milk components, and reproductive performance. Furthermore, we hypothesized that $\triangle \mathrm{BCS}$ is mainly explained by BCS at dry-off (BCSD) and that BCSD is a consequence of reproductive and productive performance. 


\section{OBJECTIVES}

The objectives of the current study were to evaluate the association between $\triangle \mathrm{BCS}$ and postpartum health and performance of lactating Holstein cows. Additionally, the current study aimed to determine factors associated with $\triangle \mathrm{BCS}$ in the dry-period and BCSD. 


\title{
4 ASSOCIATION BETWEEN BODY CONDITION SCORE CHANGE DURING THE DRY-PERIOD AND POSTPARTUM HEALTH AND PERFORMANCE
}

\begin{abstract}
The objectives of the current study were to determine the association between body condition score change during the dry-period ( $\triangle B C S$ ) and postpartum health and reproductive and productive performance of Holstein cows. Data from 16,104 lactations from 9,950 parous cows from two dairies located in the San Joaquin Valley of California were used. Within dairy, cows were scored for body condition at dry-off and parturition by the same herdsmen, who were trained by veterinarians from the Veterinary Medicine Teaching and Research Center of the University of California Davis. Cows were classified as having excessive loss of BCS (ELBCS, $\triangle \mathrm{BCS} \leq-0.75 ; \mathrm{n}=1,604)$, moderate loss of BCS (MLBCS, $\triangle \mathrm{BCS}=-0.5$ to $-0.25 ; \mathrm{n}=6,430$ ), no change in BCS (NCBCS, $\triangle \mathrm{BCS}=0 ; \mathrm{n}=4,819)$, and gained BCS (GBCS, $\triangle \mathrm{BCS} \geq 0.25 ; \mathrm{n}$ $=3,251$ ). Data regarding morbidity, mortality, and reproductive and productive performance were recorded until $305 \mathrm{~d}$ postpartum or until cows were dried-off or left the herd. Loss of BCS during the dry-period was associated with greater incidence of uterine disease and indigestion. Additionally, loss of BCS during the dry-period was associated with greater likelihood of treatment with antimicrobials, anti-inflammatory, and supportive therapy. Loss of BCS during the dry-period was associated with reduced likelihood of pregnancy after the first and second postpartum inseminations. Cows that gained BCS during the dry-period had greater yield of milk, fat, and protein and had reduced somatic cell linear score in the subsequent lactation. In the current study, loss of BCS during the dry-period was a predisposing factor associated with health disorders and reduced productive and reproductive performance in Holstein cows.
\end{abstract}

Keywords: Body condition score, dry-period, lactating dairy cows, performance 


\subsection{INTRODUCTION}

The prepartum period has been identified as critical to the health and performance of lactating dairy cows. Cows that have decreased DMI during the prepartum period and that have greater decrease in DMI in the last days of gestation are more likely to have impaired innate immunity (HAMMON et al., 2006) and are more likely to have health disorders (HUZZEY et al., 2007). Although not completely understood, the association between reduced DMI peripartum and impaired innate immunity is likely a consequence of several factors such as reduced IGF-I concentrations (INOUE et al., 1998; SANDER et al., 2011; WATHES et al., 2009), increased concentrations of non-esterified fatty acid peripartum (KLUCINSKI et al., 1988; RUKKWAMSUK; KRUIP; WENSING, 1999; HAMMON et al., 2006), and increased BHB concentrations postpartum (ERB; GROHN, 1988; GROHN et al., 1989; CORREA; ERB; SCARLETT, 1993). A strong positive correlation exists between prepartum and postpartum DMI (GRUMMER; MASHEK; HAYIRLI, 2004), suggesting that by minimizing the decline in DMI prepartum greater milk yield and improved performance should be obtained. Others have suggested that improvements in metabolic parameters may be achieved by restricting energy intake during the last weeks of gestations, with positive effects on reproductive performance (CARDOSO et al., 2013), but questions remain regarding the effects of restricted energy intake prepartum on subsequent milk yield. In large dairy herds, monitoring individual DMI is not possible and herds that attempt to measure it evaluate DMI of a group and not individuals. Body condition score and BCS change may, however, be used as indirect measures of fatness and energy balance, respectively, for individual cows (ROCHE et al., 2009).

Reduced BCS at calving is associated with lower milk yield and reduced likelihood of pregnancy, whereas elevated BCS at calving is associated with greater likelihood of postpartum metabolic diseases (reviewed by ROCHE et al., 2009). Holstein North American cows with $\mathrm{BCS}>4$ in the prepartum period tend to have a more dramatic decrease in peripartum DMI and more pronounced and prolonged negative energy balance postpartum compared with thinner cows (reviewed by GRUMMER; MASHEK; HAYIRLI, 2004). As such, cows with elevated BCS at parturition are more likely to have hepatic lipidosis, ketosis, and displacement of abomasum (OSPINA et al., 2010; ROCHE et al., 2009). Little is known, however, regarding the association between BCS change during the dry-period ( $\triangle \mathrm{BCS}$ ) and postpartum health of dairy cows. CONTRERAS, RYAN, and OVERTON (2004) demonstrated that cows with BCS $\leq 3$ at dry-off gained BCS during the dry period and were less likely to have retained fetal 
membranes compared with cows with $\mathrm{BCS} \geq 3.25$ at dry-off. Cows managed from late gestation up to $21 \mathrm{~d}$ prior to the expected calving date to be thinner (2.75 vs. 3.25) had neutrophils with reduced inflammatory state and an enhanced capacity for microbial destruction (CROOKENDEN et al., 2017). KADIVAR, AHMADI, and VATANKHAH (2014) suggested, however, that reduced BCS 2 weeks prepartum was associated with increased incidence of clinical endometritis, but change in BCS from 2 weeks prepartum to 2 or 4 weeks postpartum was not associated with clinical endometritis.

The hypothesis of the current study was that $\triangle \mathrm{BCS}$ is associated with incidence of postpartum health disorders, yield of milk and milk components, and reproductive performance. Furthermore, we hypothesized that $\triangle \mathrm{BCS}$ is mainly explained by BCS at dry-off (BCSD) and that $\mathrm{BCSD}$ is a consequence of reproductive and productive performance. The objectives of the current study were to evaluate the association between $\triangle \mathrm{BCS}$ and postpartum health and performance of lactating Holstein cows. Additionally, the current study aimed to determine factors associated with $\triangle \mathrm{BCS}$ in the dry-period and BCSD.

\subsection{MATERIAL AND METHODS}

\subsubsection{Animals, Facilities, and Management}

Holstein cows from two commercial dairies located in the San Joaquin Valley of California (Kings County), within $16 \mathrm{~km}$ of the city of Hanford, CA, were used in this retrospective observational study. Only data from parous cows ( $\geq 1$ st lactation at dry-off) that had gestation length of 256 to 296 d (VIEIRA-NETO et al., 2017) and that remained in the dryperiod for 21 to $100 \mathrm{~d}$ were used. A total of 5,263 lactations from 3,026 cows from dairy A and 10,841 lactations from 6,924 cows from dairy B met the enrollment criteria and were used in the current study. During the study period the mean rolling herd was $11,329 \mathrm{Kg} / \mathrm{cow}$ in dairy A and $10,691 \mathrm{~kg} / \mathrm{cow}$ in dairy B. Lactating cows in dairy A were housed in open lot corrals with capacity for 140 cows. Lactating cows in dairy B were housed in free-stall pens with capacity for 160 or 350 cows. During the lactation cows were fed diets formulated to meet or exceed nutrient requirements for lactating Holstein cows weighing $650 \mathrm{Kg}$ and producing $45 \mathrm{Kg}$ of $3.5 \%$-FCM (NRC, 2001). During the dry-period, cows were fed two diets (one from 60 to $25 \mathrm{~d}$ 
prior to the expected calving date, and one from $24 \mathrm{~d}$ prior to the expected calving date to

calving) formulated to meet the requirements of non-lactating Holstein cows weighing $725 \mathrm{Kg}$, with conceptus gaining approximately $0.6-0.7 \mathrm{Kg} / \mathrm{d}$, and DM intake between 15 (60 to $25 \mathrm{~d}$ prior to the expected calving date) and $10 \mathrm{Kg} / \mathrm{d}$ ( $24 \mathrm{~d}$ prior to the expected calving date to calving; NRC, 2001).

Cows were dried-off at approximately $220 \mathrm{~d}$ of gestation. At dry-off, cows received an intra-mammary treatment with a long acting antimicrobial for the prevention of mastitis. In dairy A, cows were housed in open lot corrals during the entire dry-period. In dairy B, far-off (60 to $25 \mathrm{~d}$ prior to the expected date of parturition) cows were housed in either open lot corrals or free-stall pens and close-up ( $25 \mathrm{~d}$ prior to the calving date to parturition) cows were housed in open-lot corrals.

\subsubsection{Body Condition Scoring and Classification}

Body condition score was assessed on the day cows were dried-off and at the maternity pen immediately after parturition. The herd personnel was trained by veterinarians of the Veterinary Medicine Teaching and Research Center of the University of California Davis to use the visual technique to determine the BCS on a scale of 1 (severe under conditioning) to 5 (severe over conditioning) with 0.25 increment (FERGUSON; GALLIGAN; THOMSEN, 1994). Cows were classified according to $\triangle \mathrm{BCS}$ as excessive loss (ELBCS; $\triangle \mathrm{BCS} \leq-0.75$ unit), moderate loss (MLBCS; $\triangle \mathrm{BCS}=-0.50$ to -0.25$)$, no change $(\mathrm{NCBCS} ; \triangle \mathrm{BCS}=0)$, and gained $\mathrm{BCS}$ (GBCS; $\triangle \mathrm{BCS} \geq 0.25$ ) during the dry-period. Moderate loss of BCS included cows with $\triangle \mathrm{BCS}-0.50$ and -0.25 because in a preliminary analysis of pregnancy to first postpartum AI and mean milk yield in the first 60 DIM no differences were observed between these cows, but cows with $\triangle \mathrm{BCS}=-0.50$ and cows with $\triangle \mathrm{BCS}=-0.25$ were different compared with GBCS cows. 


\subsubsection{Data Collection}

Data regarding parity (primiparous vs. multiparous), length of the dry-period, length of gestation, date of calving, calf sex (female vs. male), and number of calves born (singleton vs. twins) were collected from the on-farm computer software (Dairy Comp 305; Valley Ag Software, Tulare, CA). Gestation length was classified as short (SGL $\leq 273)$, normal (NGL = 274-283), and long (LGL > 284). Length of the dry-period was classified as short (SDP $\leq 47$ ), normal (NDP $=48-69)$, and long (LDP > 70). The classification of gestation and dry-period lengths were determined by subtracting/adding 1 standard deviation to the mean of the population. Weather data was collected from the weather station at the Visalia airport, which was located approximately $24 \mathrm{~km}$ from each of the dairies. Daily temperature humidity index (THI) was calculated. Percentages of days with THI $\geq 72$ during the $60 \mathrm{~d}$ prior to dry-off and during the dry-period were recorded. Cows were classified as exposed to no heat stress (NHS) when $<35 \%$ of days had $\mathrm{THI} \geq 72$, whereas cows were classified as being exposed to heat stress (HS) when $\geq 35 \%$ of days had THI $\geq 72$. The classification of exposure to heat stress was determined by adding 1 standard deviation to the mean of percentage of days with $\mathrm{THI} \geq 72$ for the study population.

\subsubsection{Disease Definition}

Disease diagnosis and treatment and data collection and input into the on-farm software (Dairy Comp 305; Valley Ag Software, Tulare, CA) was performed by dairy personnel trained and supervised by veterinarians of the Veterinary Medicine Teaching and Research Center of the University of California Davis. Cows were observed daily from parturition to $21 \mathrm{~d}$ postpartum for milk fever, retained fetal membranes, and metritis. A case of milk fever was defined as a prostrated cow with minimal rumen contractions that responded to intra-venous calcium treatment within $30 \mathrm{~min}$. Retained fetal membranes was defined as the failure to detach the fetal membranes within $24 \mathrm{~h}$ postpartum. Metritis was characterized by the presence of fetid, watery, red/pink uterine discharge within the first $21 \mathrm{~d}$ postpartum. From parturition to $60 \mathrm{~d}$ postpartum occurrence of ketosis, displacement of the abomasum, mastitis, indigestion, respiratory disease, lameness, and prostration without a confirmed diagnosis were recorded. 
Cows with decreased appetite and altered pattern of milk production had urine tested for ketone bodies (KetoStix, Bayer Diagnostics, Tarrytown, NY) and those that tested at or above "moderate" were classified as ketotic. Cows with a metallic ("ping") sound at percussion/auscultation of the left or right abdomen (between the 4th and 13th rib) were diagnosed with displacement of abomasum. Displacement of abomasum was confirmed by laparotomy to correct the displacement of abomasum. Cows with scant manure, lack of appetite, and rumen stasis were diagnosed with indigestion. Respiratory disease was characterized by panting, rectal temperature $>39.5{ }^{\circ} \mathrm{C}$, and crackling, rales, or percussion dullness when auscultating the lungs. Cows presenting prostration, fever (rectal temperature $>39.5{ }^{\circ} \mathrm{C}$ ), anorexia, dehydration, and depressed without a confirmed diagnosis for the diseases described previously within $0 \pm 7 \mathrm{~d}$ were recorded as undefined sickness. Occurrence of retained fetal membranes and metritis were grouped into one variable, uterine disease. Milk fever, ketosis, and displacement of abomasum were grouped into one variable, metabolic disease. Cows with a diagnosis of respiratory disease and cows with undefined sickness were grouped into other diseases.

Additionally, all treatments from parturition to $60 \mathrm{~d}$ postpartum were recorded and were grouped into parenteral (except for intra-mammary) antimicrobials, oral and parenteral antiinflammatories, and supportive therapy (e.g. oral drench, intra-venous fluids). Number of treatments in the first $60 \mathrm{~d}$ postpartum was recorded and, within category, treatments occurring in $<7 \mathrm{~d}$ intervals were considered one treatment and treatments occurring in $\geq 7 \mathrm{~d}$ intervals were considered two treatments.

Cows with traumatic events (e.g. cesarean-section, udder/teat cuts, broken limb) were excluded from the study $(n=640)$. Health records of all cows were inspected and cows with clinical diseases (e.g. mastitis, indigestion, lameness, etc.) and cows receiving antimicrobial, anti-inflammatory, and supportive therapies during the last $150 \mathrm{~d}$ of gestation were excluded from the study $(\mathrm{n}=1,605)$. 


\subsubsection{Reproductive Management and Performance}

Cows had their estrous cycle presynchronized with two injections of prostaglandin $F_{2 \alpha}$ given $14 \mathrm{~d}$ apart. Cows not observed in estrus within 12 to $14 \mathrm{~d}$ after the second prostaglandin $\mathrm{F}_{2 \alpha}$ of the presynchronization protocol were submitted to an ovulation synchronization protocol (e.g. Ovsynch56, Ovsynch48, Cosynch72, 5dCosynch72; http://www.dcrcouncil.org/media/Public/Dairy Cow Reproduction Protocols Final0930201

5.pdf). Cows observed in estrus after AI were re-inseminated in the same morning. Daily, cows were observed for signs of estrus, which included removal of tail paint, vaginal mucous discharge, increased nervousness and activity, swelling and reddening of the vulva, or standing to be mounted. Cows were examined for pregnancy between $35 \pm 7 \mathrm{~d}$ after AI, being that pregnancy exams between 28 and $34 \mathrm{~d}$ after AI were conducted by trans-rectal ultrasound and pregnancy exams between 35 and $42 \mathrm{~d}$ were conducted by transrectal manual palpation of the reproductive organs. Cows diagnosed pregnant were re-examined for pregnancy $67 \pm 3 \mathrm{~d}$ after AI by transrectal manual palpation of the reproductive organs. Cows diagnosed not pregnant at pregnancy exam were submitted to an ovulation synchronization protocol.

Pregnancies per AI (P/AI) after the first and second examinations after the first and second postpartum AI were calculated and the percentages of pregnant cows that had pregnancy loss between the first and second pregnancy examinations after the first and second postpartum inseminations were calculated. Hazard of pregnancy was calculated for all cows up to $305 \mathrm{~d}$ postpartum and cows were censored when they left the herd or were deemed ineligible for insemination by farm personnel.

\subsubsection{Milk Production Data Collection}

In both herds, cows were milked thrice daily. Herds were enrolled in the regular Dairy Herd Improvement Association program for approximately $66 \%$ of the study period and monthly yield of milk and milk components and somatic cell count were recorded for individual cows. Data regarding milk fat and protein content, 3.5\%-FCM yield, and somatic cell linear score were available for approximately $68.3 \%$ of milk records. In the current study, the first milk test in the lactation was between 5 and 34 DIM and milk yield records before 5 DIM were 
not used. Milk yield data was collected up to $305 \mathrm{~d}$ postpartum or until the cow was dried-off or left the herd. Somatic cell linear score within 60 d prior to dry-off from 9,837 lactations was evaluated to determine whether differences in somatic cell linear score postpartum could result from a carryover effect of the previous lactation. Cows from both dairies were treated with bST (Posilac, sometribove zinc suspension for injection, Elanco Animal Health, Greenfield, IN) every $14 \mathrm{~d}$ from $70 \pm 3$ DIM up to $14 \mathrm{~d}$ before the expected dry off date.

\subsubsection{Statistical Analysis}

This was a retrospective observational study. Body condition score at dry-off and $\triangle \mathrm{BCS}$ were analyzed by ANOVA using the MIXED procedure of SAS. Independent variables included in the analysis of factors associated with BCSD included dairy, parity (primiparous vs. multiparous), calf sex (female vs. male), number of calves born (singleton vs. twins), $305 \mathrm{~d}$ mature equivalent milk yield at the end of the lactation, interval from calving to conception, and exposure to heat stress $60 \mathrm{~d}$ prior to dry-off. The statistical model for analysis of factors associated with $\triangle \mathrm{BCS}$ included dairy, parity, calf sex, number of calves born, dry-period length, gestation length, exposure to heat stress during the dry-period, and BCSD. Cow was included in the as a random effect. The likelihood of GBCS during the dry-period was analyzed by logistic regression using the GLIMMIX procedure of SAS (SAS/STAT®, SAS Inst. Inc., Cary, NC) with the logit function and binomial distribution. The statistical model for analysis of factors associated with the likelihood of GBCS during the dry-period included dairy, parity, calf sex, number of calves born, dry-period length, gestation length, exposure to heat stress during the dry-period, and BCSD (continuous: linear, quadratic, cubic). Cow was included in the as a random effect. Independent variables with $\mathrm{P}>0.05$ were manually removed until all variables left had $\mathrm{P} \leq 0.05$. Receiver operator characteristics was used to determine the BCSD that predicted GBCS with the highest sensitivity and specificity (Medcalc, Ostend, Belgium).

Binomial data (e.g. likelihood of disease, likelihood of treatment, likelihood of pregnancy) were analyzed by logistic regression using the GLIMMIX procedure of SAS (SAS/STAT®, SAS Inst. Inc., Cary, NC) with the logit function and binomial distribution. Time dependent variables (e.g. hazard of removal from the herd and hazard of pregnancy) were analyzed by Cox proportional hazard regression analysis using the PHREG procedure of SAS. The statistical models included $\triangle \mathrm{BCS}$, dairy, parity, calf sex, number of calves born, gestation 
length, dry-period length, exposure to heat stress, and the interactions between $\triangle \mathrm{BCS}$ and dairy, $\triangle \mathrm{BCS}$ and parity, $\triangle \mathrm{BCS}$ and gestation length, $\triangle \mathrm{BCS}$ and length of the dry-period, and $\triangle \mathrm{BCS}$ and exposure heat stress. The statistical models to evaluate the association between $\triangle \mathrm{BCS}$ and P/AI and pregnancy loss also included insemination code (estrus vs. fixed time). Cow was included in the as a random effect. Independent variables with $\mathrm{P}>0.05$ were manually removed from the logistic regression models until all variables left had $\mathrm{P} \leq 0.05$. The Cox proportional hazard regression models removed independent variables by a backward elimination based on the Wald's statistics criterion when $\mathrm{P}>0.05$. The associations between $\triangle \mathrm{BCS}$ and the interval from parturition to removal from the herd and from parturition to establishment of pregnancy were analyzed by survival analysis using the product limit method of the Kaplan-Meier model by the LIFETEST procedure of the SAS.

Continuous data with repeated measures such milk yield, yield of milk components, and somatic cell linear score were analyzed by ANOVA using the MIXED procedure of SAS using the repeated statement. The statistical models included $\triangle \mathrm{BCS}$, dairy, parity, calf sex, number of calves born, gestation length, dry-period length, exposure to heat stress, month of lactation, and the interactions between $\triangle \mathrm{BCS}$ and dairy, $\triangle \mathrm{BCS}$ and parity, $\triangle \mathrm{BCS}$ and gestation length, $\triangle \mathrm{BCS}$ and length of the dry-period, $\triangle \mathrm{BCS}$ and exposure heat stress, and between $\triangle \mathrm{BCS}$ and month of lactation. Cow was included in the as a random effect. Independent variables with $\mathrm{P}$ $>0.05$ were manually removed from the logistic regression models until all variables left had $\mathrm{P} \leq 0.05$.

For each of the statistical models collinearity was tested using the REG procedure of SAS with the "collin" and "VIF" functions. Variables with variance inflation factors $\geq 1.5$ were considered collinear. In such cases, each variable was added to the model separately and the variable with the smallest $\mathrm{P}$-value was retained. Statistical significance was defined as $\mathrm{P} \leq 0.01$ and statistical tendencies as $0.01<\mathrm{P} \leq 0.05$.

\subsection{RESULTS}

The mean BCS $( \pm$ SEM) at dry-off were $4.08 \pm 0.006,3.75 \pm 0.004,3.51 \pm 0.004$, and $3.29 \pm 0.005$ for ELBCS, MLBCS, NCBCS, and GBCS cows, respectively, and the mean BCS $( \pm$ SEM) at calving were $3.19 \pm 0.007,3.37 \pm 0.005,3.47 \pm 0.005$, and $3.58 \pm 0.006$ for ELBCS, MLBCS, NCBCS, and GBCS cows, respectively (Figure 1). 
Figure 1 - Distribution of body condition score (BCS) at dry-off (A), BCS change during the dryperiod (B), and BCS at calving (C) according to dairy, and mean ( \pm SEM) BCS at dry-off and BCS at calving according to change in BCS during the dry-period ( $\triangle \mathrm{BCS}$; panel D). ELBCS: cows with $\triangle \mathrm{BCS} \leq-0.75$, MLBCS: cows with $\triangle \mathrm{BCS}=-0.5$ to -0.25 , NCBCS: cows with $\triangle \mathrm{BCS}=0$, GBCS: cows with $\triangle \mathrm{BCS} \geq 0.25$.
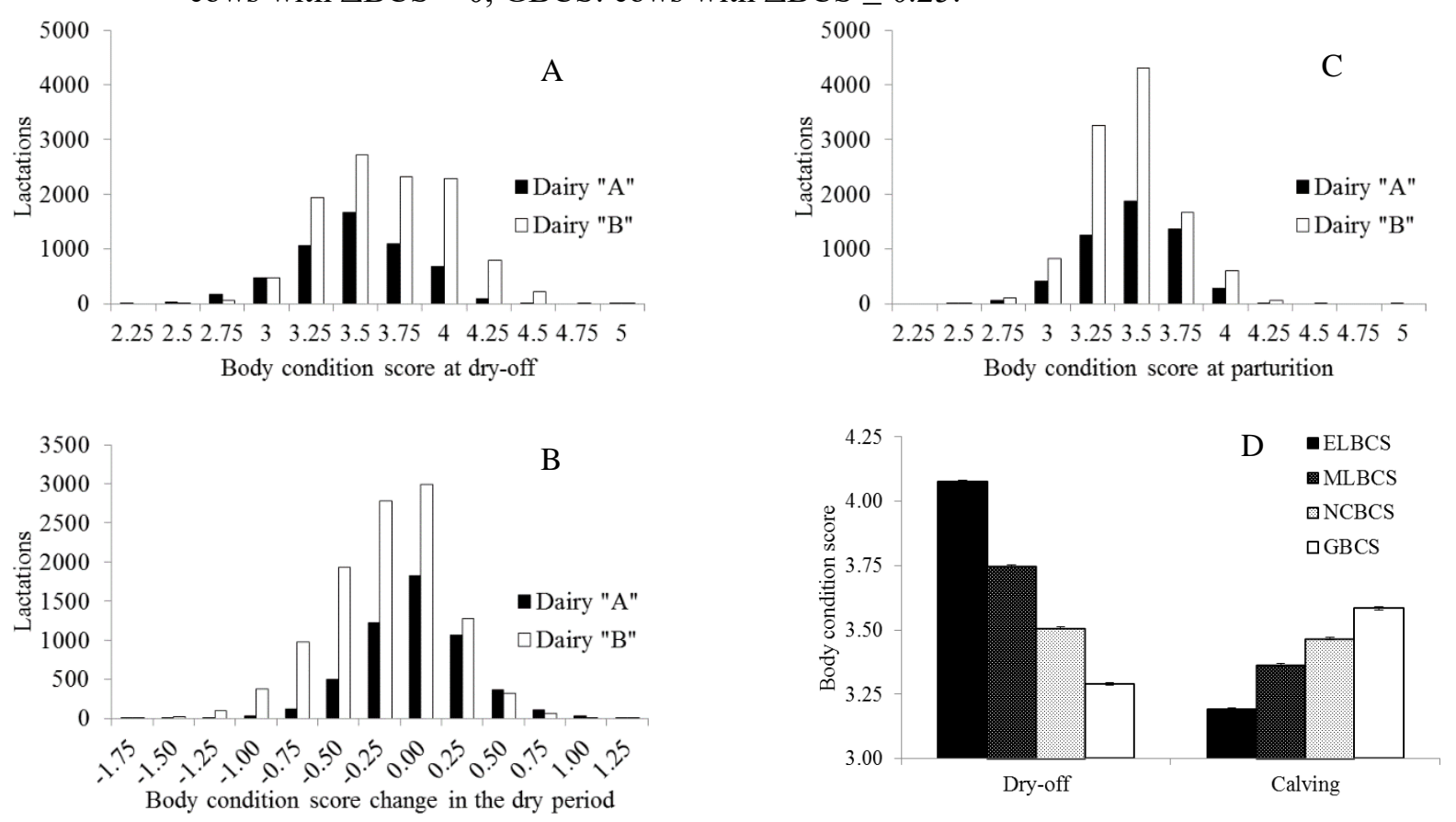

Factors associated with BCSD were dairy $(\mathrm{A}=3.52 \pm 0.01, \mathrm{~B}=3.67 \pm 0.01 ; \mathrm{P}<0.001)$, parity (primiparous $=3.55 \pm 0.01$, multiparous $=3.65 \pm 0.01 ; \mathrm{P}<0.001$ ), $305 \mathrm{~d}$ mature equivalent milk yield $(\mathrm{P}<0.001)$, interval from calving to conception $(\mathrm{P}<0.001)$, and exposure to heat stress in the last $60 \mathrm{~d}$ prior to dry-off $(\mathrm{P}=0.003)$. Individual cow explained $54.0 \%$ of the variability in BCSD, whereas the independent variables explained only $6.9 \%$ of the variability in BCSD. Parity, dairy, and $305 \mathrm{~d}$ mature equivalent milk yield made the greatest contribution to the variability in BCSD explained by the model (Figure 2 A). Factors associated with $\triangle \mathrm{BCS}$ were BCSD $(\mathrm{P}<0.001)$, dairy $(\mathrm{P}<0.001)$, parity $(\mathrm{P}<0.001)$, gestation length $(\mathrm{P}$ $<0.001)$, dry-period length ( $\mathrm{P}<0.001), 305 \mathrm{~d}$ mature equivalent milk yield ( $\mathrm{P}<0.001)$, calf sex $(\mathrm{P}<0.001)$, and number of calves born $(\mathrm{P}<0.001)$. Individual cow explained $22.4 \%$ of the variability in $\triangle \mathrm{BCS}$, but the independent variables explained $57.4 \%$ of the variability in $\triangle \mathrm{BCS}$. Body condition score at dry-off made the greatest contribution to the variability in $\triangle \mathrm{BCS}$ explained by the model (Figure $2 \mathrm{~B}$ ). 
Figure 2 - Proportion of variation (\%) in body condition score (BCS) at dry-off (A) and BCS change during the dry-period (B) explained by independent variables retained in the multivariate model. R2 of multivariate model for BCS at dry-off $=6.9 \%$ (dairy $=38 \%$, parity $=44 \%$, days open $=4 \%, 305-\mathrm{d} \mathrm{ME}=14 \%$, heat stress $=1 \%$ ). $\mathrm{R} 2$ of multivariate model for BCS change during the dry-period $=57.4 \%$ (dairy $=0.8 \%$, parity $=2.6 \%$, length of the dry period $=0.5 \%$, BCS at dry-off $=94.7 \%$, percentage of days with $\mathrm{THI} \geq 72=0.04 \%$, calf sex $=0.09 \%$, number of calves born $=1.2 \%$ ). 305-d $\mathrm{ME}=305 \mathrm{~d}$ milk yield mature equivalent.
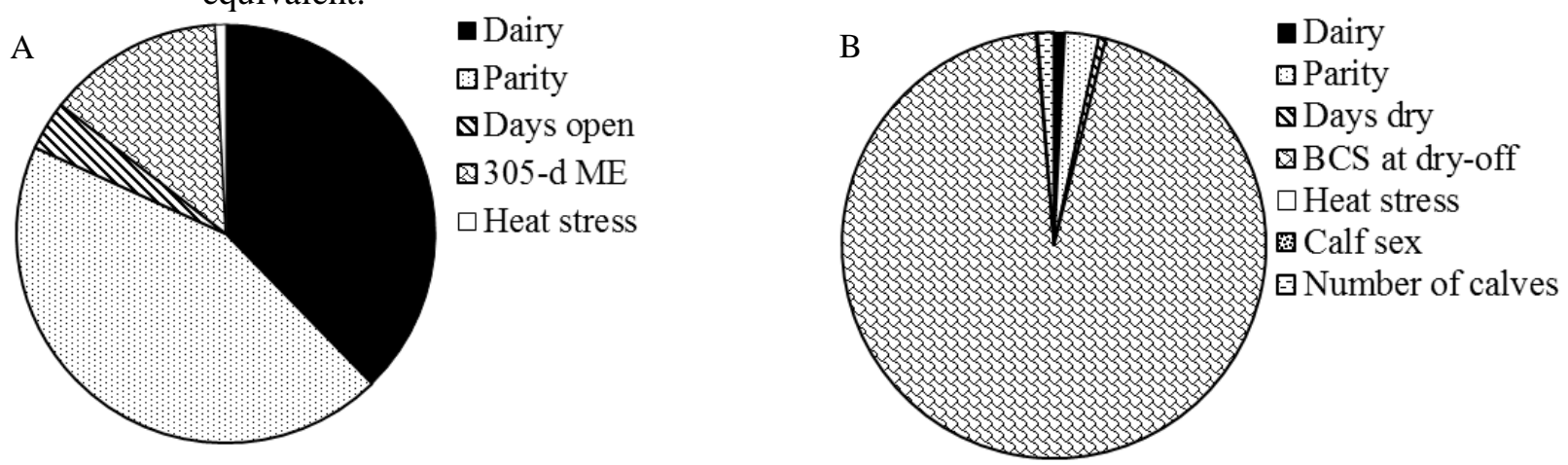

The probability of GBCS was dependent on dairy ( $\mathrm{P}<0.001)$, parity $(\mathrm{P}<0.001)$, BCSD (linear $-\mathrm{P}=0.02$; quadratic $-\mathrm{P}<0.001$; Figure 3), length of the dry-period $(\mathrm{P}<0.001)$, and number of calves born $(\mathrm{P}<0.001)$. The adjusted odds ratio $(\mathrm{AOR})$ and $95 \%$ confidence intervals $(95 \% \mathrm{CI})$ for factors associated with GBCS were: dairy $-\mathrm{A}=1.47(1.32,1.63), \mathrm{B}=$ referent; parity - primiparous $=0.53(0.48,0.58)$, multiparous $=$ referent; length of the dryperiod $-\mathrm{SDP}=0.70(0.60,0.82), \mathrm{NDP}=$ referent, $\mathrm{LDP}=1.33(1.14,1.54)$; number of calves born - singleton $=3.23(2.52,4.14)$, twins $=$ referent. The receiver operator characteristics analysis indicated that the BCSD that most accurately predicted the likelihood of GBCS was $\mathrm{BCSD} \leq 3.25$ (sensitivity $=70.0 \%$, specificity $=85.1 \%$; area under the curve $=0.86,95 \% \mathrm{CI}=$ $0.85,0.86 ; \mathrm{P}<0.001)$.

Figure 3 - Probability of cows gaining BCS during the dry-period (GBCS) according to BCS at dryoff based on the results of the multivariate logistic regression. Effect of: BCS at dry-off (linear $-\mathrm{P}=0.02$, quadratic $-\mathrm{P}<0.001)$, dairy $(\mathrm{P}<0.001)$, parity $(\mathrm{P}<0.001)$, length of the dry-period $(\mathrm{P}<0.001)$, and number of calves born $(\mathrm{P}<0.001)$.

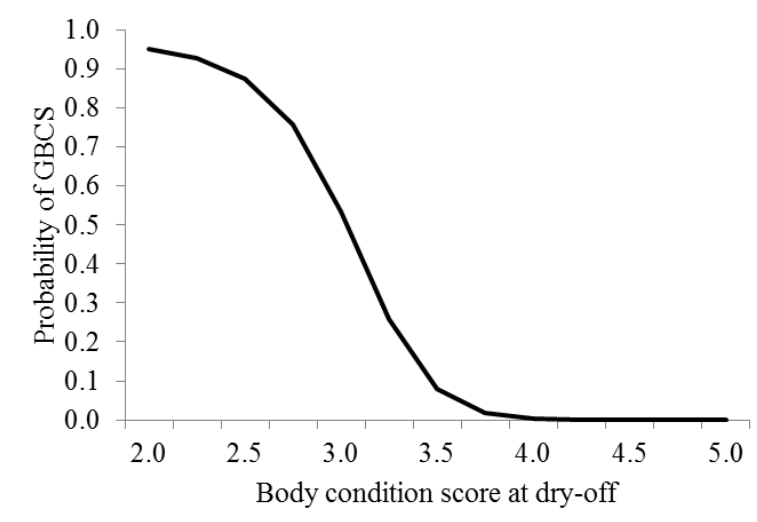




\subsubsection{Association between $\triangle \mathrm{BCS}$ and Health Outcomes}

There was a tendency $(\mathrm{P}=0.04)$ for the interaction between $\triangle \mathrm{BCS}$ and length of the dry-period to be associated with the likelihood of stillbirth. Among cows with NDP, incidence of stillbirth was relative constant according to $\triangle \mathrm{BCS}$ (ELBCS $=3.60, \mathrm{MLBCS}=4.15, \mathrm{NCBCS}$ $=4.23, \mathrm{GBCS}=3.22 \%$ ). Among cows with SDP, incidence of stillbirth was higher for NCBCS cows $(\mathrm{ELBCS}=5.80, \mathrm{MLBCS}=5.13, \mathrm{NCBCS}=6.99, \mathrm{GBCS}=4.85 \%)$, whereas the incidence of stillbirth among cows with LDP was higher for ELBCS and MLBCS cows (ELBCS = 7.14, MLBCS $=7.34, \mathrm{NCBCS}=3.31, \mathrm{GBCS}=4.31 \%)$. There was a tendency $(\mathrm{P}=0.04)$ for primiparous cows $(\mathrm{AOR}=0.84,95 \% \mathrm{CI}=0.71,0.99)$ to be less likely to have stillbirths than multiparous cows. Additionally, cows that delivered female $(\mathrm{AOR}=0.55,95 \% \mathrm{CI}=0.47,0.66$; $\mathrm{P}<0.001)$ and singletons $(\mathrm{AOR}=0.17,95 \% \mathrm{CI}=0.14,0.21 ; \mathrm{P}<0.001)$ calves were less likely to have stillbirths than cows that delivered male and twin calves, respectively. Gestation length was $(\mathrm{P}<0.001)$ associated with likelihood of stillbirth because cows with SGL were (AOR = $2.32,95 \% \mathrm{CI}=1.89,2.86$ ) more likely to have stillborn calves compared with NGL (referent) and $\mathrm{LGL}(\mathrm{AOR}=1.20,95 \% \mathrm{CI}=0.94,1.53)$. Cows that were not exposed to heat stress during the dry-period were $(\mathrm{AOR}=0.78,95 \% \mathrm{CI}=0.84,0.93 ; \mathrm{P}=0.007)$ less likely to deliver stillborn calves.

There was $(\mathrm{P}<0.001)$ an association between $\triangle \mathrm{BCS}$ and likelihood of uterine disease (Table 1). Cows with ELBCS were $(\mathrm{P}<0.001)$ more likely to be diagnosed with uterine disease than MLBCS, NCBCS, and GBCS cows. Although the likelihood of uterine disease did not (P $=0.34)$ differ between MLBCS and NCBCS cows, MLBCS cows were $(\mathrm{P}=0.002)$ and NCBCS cows tended $(\mathrm{P}=0.03)$ to be more likely to be diagnosed with uterine disease than GBCS cows. Cows from dairy A were $(\mathrm{P}<0.001)$ more likely to be diagnosed with uterine diseases than cows from dairy B (Table 1). Additionally, gestation length was $(\mathrm{P}<0.001)$ associated with the likelihood of uterine disease because cows with SGL were more likely to be diagnosed with uterine disease than NGL and LGL cows (Table 1). Dry-period length was $(\mathrm{P}<0.001)$ associated with the likelihood of uterine disease because cows with SDP and LDP were more likely to be diagnosed with uterine disease than cows with NDP (Table 1).

Change in BCS during the dry-period was not $(\mathrm{P}=0.36)$ associated with the likelihood of metabolic diseases. Cows from dairy A were $(\mathrm{AOR}=12.4,95 \% \mathrm{CI}=9.28,16.57 ; \mathrm{P}<0.001)$ more likely to have metabolic diseases than cows from dairy B. Primiparous cows were (AOR $=0.24,95 \% \mathrm{CI}=0.18,0.30 ; \mathrm{P}<0.001)$ less likely to have metabolic diseases than multiparous 
cows. Additionally, cows that delivered female calves tended to be $(\mathrm{AOR}=0.80,95 \% \mathrm{CI}=$ 0.65, 0.98; $\mathrm{P}=0.03)$ and cows that delivered singletons were $(\mathrm{AOR}=0.38,95 \% \mathrm{CI}=0.29$, $0.50 ; \mathrm{P}<0.001)$ less likely to have metabolic diseases than cows that delivered male and twin calves, respectively. Length of the dry-period was $(\mathrm{P}<0.001)$ associated with the likelihood of metabolic diseases because $\mathrm{LDP}$ cows were $(\mathrm{AOR}=1.70,95 \% \mathrm{CI}=1.36,2.13)$ more likely to have metabolic diseases compared with NDP (referent) and $\mathrm{SDP}(\mathrm{AOR}=1.50,95 \% \mathrm{CI}=0.96$, 2.35).

Table 1. Final logistic regression model of factors associated with uterine diseases postpartum

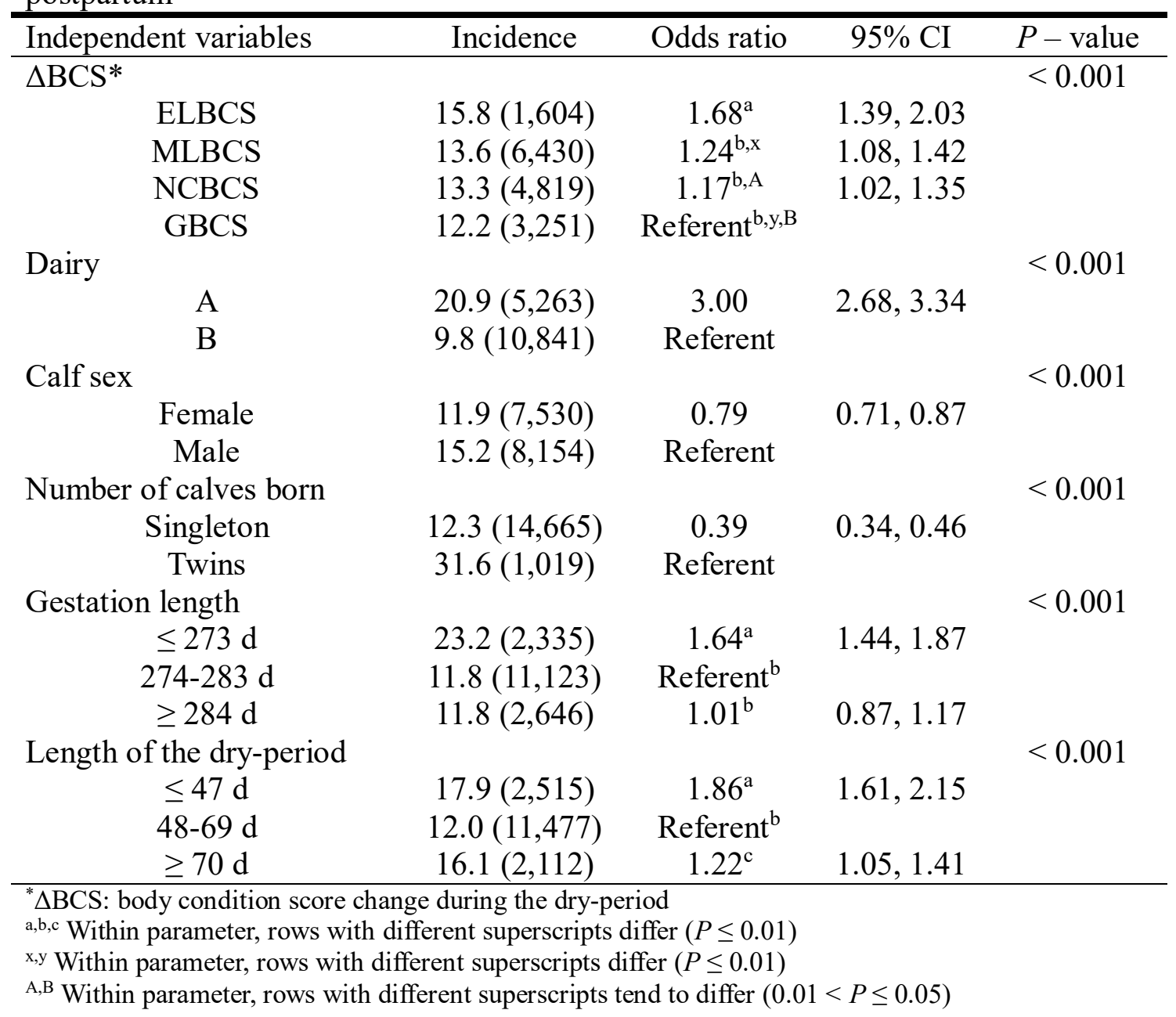

The interaction between $\triangle \mathrm{BCS}$ and parity tended $(\mathrm{P}=0.03)$ to be associated with the likelihood of indigestion (Table 2). Primiparous cows with ELBCS and GBCS had reduced incidence of indigestion compared with MLBCS and NCBCS primiparous cows (ELBCS = $1.11, \operatorname{MLBCS}=2.48, \mathrm{NCBCS}=2.03, \mathrm{GBCS}=1.17 \%$ ), but the likelihood of indigestion was greatest among ELBCS multiparous cows and lowest among GBCS multiparous cows (ELBCS $=5.35, \operatorname{MLBCS}=4.39, \mathrm{NCBCS}=3.55, \mathrm{GBCS}=2.94 \%$ ). 
Cows that delivered singletons were $(\mathrm{P}<0.001)$ less likely to have indigestion than cows that delivered twins (Table 2). Length of the dry-period was $(\mathrm{P}<0.001)$ associated with the likelihood of indigestion because cows with SDP and LDP were more likely to have indigestion than cows with NDP (Table 2). Cows that were not exposed to heat stress during the dry-period were $(\mathrm{P}=0.01)$ less likely to have indigestion than cows exposed to heat stress (Table 2).

Table 2. Final logistic regression model of factors associated with indigestion within 60 d postpartum

\begin{tabular}{|c|c|c|c|c|}
\hline Independent variables & Incidence & Odds ratio & $95 \% \mathrm{CI}$ & $P$ - value \\
\hline$\Delta \mathrm{BCS}^{* \neq}$ & & & & 0.01 \\
\hline ELBCS & $2.7(1,604)$ & $1.03^{\mathrm{A}}$ & $0.65,1.63$ & \\
\hline MLBCS & $3.4(6,430)$ & $1.58^{\mathrm{a}, \mathrm{B}}$ & $1.16,2.17$ & \\
\hline $\mathrm{NCBCS}$ & $2.8(4,819)$ & $1.40^{\mathrm{X}}$ & $1.01,1.95$ & \\
\hline GBCS & $2.2(3,251)$ & Referent $^{\mathrm{b}, \mathrm{Y}}$ & & \\
\hline Parity & & & & $<0.001$ \\
\hline Primiparous & $2.0(8,161)$ & 0.39 & $0.30,0.50$ & \\
\hline Multiparous & $3.9(7,943)$ & Referent & & \\
\hline Number of calves born & & & & $<0.001$ \\
\hline Singleton & $2.7(14,665)$ & 0.56 & $0.42,0.75$ & \\
\hline Twins & $5.7(1,019)$ & Referent & & \\
\hline Length of the dry-period & & & & $<0.001$ \\
\hline$\leq 47 \mathrm{~d}$ & $4.7(2,515)$ & $2.44^{\mathrm{a}}$ & $1.94,3.08$ & \\
\hline $48-69 d$ & $2.1(11,477)$ & Referent $^{b}$ & & \\
\hline$\geq 70 \mathrm{~d}$ & $4.8(2,112)$ & $2.06^{\mathrm{a}}$ & $1.61,2.63$ & \\
\hline $\begin{array}{l}\text { Percentage of days in the dry- } \\
\text { period with } \mathrm{THI} \geq 72\end{array}$ & & & & 0.01 \\
\hline$<35 \%$ & $2.7(12,896)$ & 0.76 & $0.61,0.94$ & \\
\hline$\geq 35 \%$ & $3.6(3,208)$ & Referent & & \\
\hline $\begin{array}{l}{ }^{*} \triangle \mathrm{BCS} \text { : body condition score change } \\
{ }^{4} \text { Interaction: } \triangle \mathrm{BCS} \times \text { Parity }(P=0.03 \\
\mathrm{a}, \mathrm{b}, \mathrm{c} \text { Within parameter, rows with diffe } \\
\mathrm{x,y} \text { Within parameter, rows with differ } \\
\mathrm{A}, \mathrm{B} \text { Within parameter, rows with diffe }\end{array}$ & $\begin{array}{l}\text { the dry-period } \\
\text { uperscripts differ } \\
\text { perscripts differ } \\
\text { perscripts tend } t\end{array}$ & $\begin{array}{l}\leq 0.01) \\
\leq 0.01) \\
\text { liffer }(0.01\end{array}$ & & \\
\hline
\end{tabular}

The interaction between $\triangle \mathrm{BCS}$ and parity tended $(\mathrm{P}=0.05)$ to be associated with the likelihood of lameness within $60 \mathrm{~d}$ postpartum. While the likelihood of lameness was lowest among $\mathrm{NCBCS}$ primiparous cows $(\mathrm{ELBCS}=2.8 \%, \mathrm{MLBCS}=2.5 \%, \mathrm{NCBCS}=1.8 \%, \mathrm{GBCS}$ $=2.6 \%$ ), the likelihood of lameness was lowest in ELBCS multiparous cows (ELBCS $=2.6 \%$, $\mathrm{MLBCS}=4.3 \%, \mathrm{NCBCS}=4.4 \%, \mathrm{GBCS}=4.2 \%)$. There was a tendency $(\mathrm{P}=0.02)$ for cows that delivered singletons to be more likely $(\mathrm{AOR}=1.68,95 \% \mathrm{CI}=1.09,2.60)$ to be lame within $60 \mathrm{~d}$ postpartum than cows that delivered twins. Cows that were not exposed to heat stress 
tended $(\mathrm{P}=0.05)$ to be less likely $(\mathrm{AOR}=0.81,95 \% \mathrm{CI}=0.65,1.00)$ to be lame than cows exposed to heat stress.

Change in BCS during the dry-period was not $(\mathrm{P}=0.07)$ associated with the likelihood of mastitis within $60 \mathrm{~d}$ postpartum. Cows from dairy A were $(\mathrm{AOR}=2.11,95 \% \mathrm{CI}=1.87$, 2.38; $\mathrm{P}<0.001)$ more likely to be diagnosed with mastitis within $60 \mathrm{~d}$ postpartum than cows from dairy $\mathrm{B}$. Primiparous cows were $(\mathrm{AOR}=0.53,95 \% \mathrm{CI}=0.47,0.60 ; \mathrm{P}<0.001)$ less likely to be diagnosed with mastitis within the first $60 \mathrm{~d}$ postpartum than multiparous cows.

There was no $(\mathrm{P}=0.29)$ association between $\triangle \mathrm{BCS}$ and the likelihood of other diseases within $60 \mathrm{~d}$ postpartum. Cows from dairy A were $(\mathrm{AOR}=8.08,95 \% \mathrm{CI}=6.49,10.06$; $\mathrm{P}<$ 0.001 ) more likely to have other diseases than cows from dairy B. Primiparous cows (AOR = $0.62,95 \% \mathrm{CI}=0.52,0.74 ; \mathrm{P}<0.001)$ and cows that delivered singletons $(\mathrm{AOR}=0.41,95 \%$ $\mathrm{CI}=0.32,0.53 ; \mathrm{P}<0.001)$ were more likely to have other diseases within $60 \mathrm{~d}$ postpartum than multiparous cows and cows that delivered twins, respectively. There was a tendency $(P=0.04)$ for the length of the dry-period to be associated with the likelihood of other diseases because LDP cows were $(\mathrm{AOR}=1.31,95 \% \mathrm{CI}=1.06,1.61)$ more likely to be have other diseases than NDP cows (referent), but SDP cows $(\mathrm{AOR}=0.93,95 \% \mathrm{CI}=0.63,1.38)$ did not differ from LDP and NDP cows.

The interaction between $\triangle \mathrm{BCS}$ and the dry-period length tended $(\mathrm{P}=0.04)$ to be associated with the likelihood of treatment with antimicrobials. Among cows with short $(\mathrm{ELBCS}=17.4 \%, \mathrm{MLBCS}=19.3 \%, \mathrm{NCBCS}=18.1 \%, \mathrm{GBCS}=14.3 \%)$ and normal $(\mathrm{ELBCS}$ $=11.9 \%, \operatorname{MLBCS}=9.9 \%, \mathrm{NCBCS}=10.6 \%, \mathrm{GBCS}=8.9 \%$ ) dry-periods, GBCS cows were less likely to be treated with antimicrobials, whereas among cows with long dry-period cows with NCBCS and GBCS were less likely to be treated with antimicrobials (ELBCS $=18.5 \%$, $\mathrm{MLBCS}=17.1 \%, \mathrm{NCBCS}=12.2 \%, \mathrm{GBCS}=13.7 \%)$. Cows from dairy A were $(\mathrm{P}<0.001)$ more likely to be treated with antimicrobials than cows from dairy B (Table 3). Primiparous cows were $(\mathrm{P}<0.001)$ less likely to be treated with antimicrobials than multiparous cows (Table $3)$. Cows that delivered female $(\mathrm{P}<0.001)$ and singletons $(\mathrm{P}<0.001)$ calves were less likely to be treated with antimicrobials than cows that delivered male and twins, respectively (Table 3 ). Gestation length was $(\mathrm{P}<0.001)$ associated with the likelihood of treatment with antimicrobials because cows with SGL were $(\mathrm{P}<0.001)$ more likely to be treated with antimicrobials than cows with NGL and LGL, whereas there was no difference between cows with NGL and LGL (Table 3). Cows that were not exposed to heat stress during the dry-period were $(\mathrm{P}<0.001)$ less likely to be treated with antimicrobials than cows exposed to heat stress (Table 3). 


\begin{tabular}{|c|c|c|c|c|}
\hline Independent variables & Incidence & $\begin{array}{l}\text { Odds } \\
\text { ratio }\end{array}$ & $95 \% \mathrm{CI}$ & $P$-value \\
\hline Body condition score change & & & & $<0.001$ \\
\hline ELBCS & $14.1(1,604)$ & $1.57^{\mathrm{a}, \mathrm{x}}$ & $1.24,2.00$ & \\
\hline MLBCS & $12.4(6,430)$ & $1.32^{\mathrm{a}}$ & $1.10,1.57$ & \\
\hline $\mathrm{NCBCS}$ & $11.8(4,819)$ & $1.15^{\mathrm{y}}$ & $0.95,1.39$ & \\
\hline GBCS & $10.1(3,251)$ & Referent $^{\mathrm{b}}$ & & \\
\hline Dairy & & & & $<0.001$ \\
\hline A & $15.9(5,263)$ & 2.06 & $1.83,2.31$ & \\
\hline B & $10.0(10,841)$ & Referent & & \\
\hline Parity & & & & $<0.001$ \\
\hline Primiparous & $9.7(8,161)$ & 0.65 & $0.58,0.72$ & \\
\hline Multiparous & $14.2(7,943)$ & Referent & & \\
\hline Calf sex & & & & $<0.001$ \\
\hline Female & $10.4(7,530)$ & 0.78 & $0.71,0.87$ & \\
\hline Male & $13.4(8,154)$ & Referent & & \\
\hline Number of calves born & & & & $<0.001$ \\
\hline Singleton & $10.9(14,665)$ & 0.44 & $0.37,0.51$ & \\
\hline Twins & $27.2(1,019)$ & Referent & & \\
\hline Gestation length & & & & $<0.001$ \\
\hline$\leq 273 \mathrm{~d}$ & $20.0(2,335)$ & $1.38^{\mathrm{a}}$ & $1.19,1.58$ & \\
\hline $2 \overline{7} 4-283 \mathrm{~d}$ & $10.6(11,123)$ & Referent $^{\mathrm{b}}$ & & \\
\hline$\geq 284 \mathrm{~d}$ & $10.3(2,646)$ & $0.98^{\mathrm{b}}$ & $0.83,1.14$ & \\
\hline Length of the dry-period & & & & $<0.001$ \\
\hline$\leq 47 \mathrm{~d}$ & $18.0(2,515)$ & $2.17^{\mathrm{a}}$ & $1.84,2.56$ & \\
\hline$\overline{48}-69 \mathrm{~d}$ & $10.0(11,477)$ & Referent $^{\mathrm{b}}$ & & \\
\hline$\geq 70 \mathrm{~d}$ & $14.9(2,112)$ & $1.31^{\mathrm{c}}$ & $1.10,1.57$ & \\
\hline $\begin{array}{l}\text { Percentage of days in the dry- } \\
\text { period with THI } \geq 72\end{array}$ & & & & $<0.001$ \\
\hline$<35 \%$ & $11.3(12,896)$ & 0.81 & $0.72,0.92$ & \\
\hline$\geq 35 \%$ & $14.4(3,208)$ & Referent & & \\
\hline
\end{tabular}

The interaction between $\triangle \mathrm{BCS}$ and parity tended $(\mathrm{P}=0.04)$ to be associated with the likelihood of treatment with anti-inflammatories. Primiparous cows that gained BCS during the dry-period were less likely to be treated with anti-inflammatories (ELBCS $=10.6 \%$, MLBCS $=8.3 \%, \mathrm{NCBCS}=7.9 \%, \mathrm{GBCS}=5.6 \%$ ). Multiparous cows those with NCBCS and GBCS were less likely to be treated with anti-inflammatories $(\mathrm{ELBCS}=18.5 \%, \mathrm{MLBCS}=11.9 \%$, $\mathrm{NCBCS}=7.8 \%$, GBCS $=7.9 \%$ ). The interaction between $\triangle \mathrm{BCS}$ and dry-period length tended $(\mathrm{P}=0.03)$ to be associated with the likelihood of treatment with anti-inflammatories. Among cows with SDP, GBCS cows were less likely to be treated with anti-inflammatories (ELBCS = $17.2 \%, \operatorname{MLBCS}=18.9 \%, \mathrm{NCBCS}=17.8 \%, \mathrm{GBCS}=13.7 \%$, whereas among cows with LDP, 
NCBCS cows were less likely to be treated with anti-inflammatories (ELBCS $=17.8 \%$, MLBCS $=12.2 \%, \mathrm{NCBCS}=6.9 \%$, GBCS $=9.1 \%$ ). Among cows with NDP, NCBCS and GBCS cows were less likely to be treated with anti-inflammatories (ELBCS $=11.4 \%$, MLBCS $=7.4 \%, \mathrm{NCBCS}=6.3 \%, \mathrm{GBCS}=5.6 \%)$. Cows from dairy A were $(\mathrm{P}<0.001)$ less likely to be treated with anti-inflammatories than cows from dairy B (Table 4). Primiparous cows were (P $<0.001$ ) less likely to be treated with anti-inflammatories than multiparous cows (Table 4). Cows that delivered female calves $(\mathrm{P}<0.001)$ and singletons $(\mathrm{P}<0.001)$ were less likely to be treated with anti-inflammatories than cows that delivered male and twin calves, respectively (Table 4). Gestation length was $(\mathrm{P}<0.001)$ associated with the likelihood of treatment with anti-inflammatories because SGL cows were more likely to be treated with anti-inflammatories followed by LGL and NGL cows, respectively (Table 4). Cows not exposed to heat stress during were $(\mathrm{P}<0.001)$ less likely to be treated with anti-inflammatories than cows exposed to heat stress (Table 4).

There was $(\mathrm{P}<0.001)$ an association between $\triangle \mathrm{BCS}$ and the likelihood of treatment with supportive therapy because ELBCS, MLBCS, and NCBCS cows were more likely to receive supportive therapy than GBCS cows (Table 5). Cows from dairy A were $(\mathrm{P}<0.001)$ more likely to receive supportive therapy than cows in dairy B (Table 5). Primiparous cows were $(\mathrm{P}<0.001)$ less likely to receive supportive therapy than multiparous cows (Table 5). Similarly, cows that delivered female $(\mathrm{P}<0.001)$ and singletons $(\mathrm{P}<0.001)$ calves were less likely to receive supportive therapy than cows that delivered male and twin calves, respectively (Table 5). Cows with SGL were $(\mathrm{P}<0.001)$ more likely to receive supportive therapy than NGL and LGL cows, but there was no difference between NGL and LGL cows (Table 5). Length of the dry-period was $(\mathrm{P}<0.001)$ associated with the likelihood of treatment with supportive therapy because LDP were $(\mathrm{P}<0.001)$ more likely to receive supportive therapy followed by SDP and NDP cows, respectively (Table 5). 
Table 4. Final logistic regression model of factors associated with treatment with parenteral anti-inflammatory within $60 \mathrm{~d}$ postpartum

\begin{tabular}{|c|c|c|c|c|}
\hline Independent variables & Incidence & Odds ratio & $95 \% \mathrm{CI}$ & $P$ - value \\
\hline Body condition score change & & & & $<0.001$ \\
\hline ELBCS & $13.7(1,604)$ & $1.57^{\mathrm{a}, \mathrm{A}}$ & $1.22,2.03$ & \\
\hline MLBCS & $10.0(6,430)$ & $1.25^{\mathrm{B}, \mathrm{X}}$ & $1.02,1.52$ & \\
\hline NCBCS & $7.9(4,819)$ & $1.04^{\mathrm{b}, \mathrm{Y}}$ & $0.83,1.29$ & \\
\hline GBCS & $6.7(3,251)$ & Referent $^{\mathrm{b}, \mathrm{Y}}$ & & \\
\hline Dairy & & & & $<0.001$ \\
\hline A & $6.8(5,263)$ & 0.77 & $0.67,0.89$ & \\
\hline B & $10.2(10,841)$ & Referent & & \\
\hline Parity & & & & $<0.001$ \\
\hline Primiparous & $8.0(8,161)$ & 0.67 & $0.59,0.76$ & \\
\hline Multiparous & $10.3(7,943)$ & Referent & & \\
\hline Calf sex & & & & $<0.001$ \\
\hline Female & $8.1(7,530)$ & 0.80 & $0.72,0.90$ & \\
\hline Male & $10.2(8,154)$ & Referent & & \\
\hline Number of calves born & & & & $<0.001$ \\
\hline Singleton & $8.4(14,665)$ & 0.45 & $0.38,0.54$ & \\
\hline Twins & $20.9(1,019)$ & Referent & & \\
\hline Gestation length & & & & $<0.001$ \\
\hline$\leq 273 \mathrm{~d}$ & $17.0(2,335)$ & $1.47^{\mathrm{a}}$ & $1.26,1.72$ & \\
\hline $274-283 \mathrm{~d}$ & $7.9(11,123)$ & Referent $^{\mathrm{b}}$ & & \\
\hline$\geq 284 \mathrm{~d}$ & $7.3(2,646)$ & $0.98^{\mathrm{b}}$ & $0.82,1.17$ & \\
\hline Length of the dry-period & & & & $<0.001$ \\
\hline$\leq 47 \mathrm{~d}$ & $17.7(2,515)$ & $2.10^{\mathrm{a}}$ & $1.77,2.48$ & \\
\hline $48-69 \mathrm{~d}$ & $7.0(11,477)$ & Referent $^{\mathrm{b}}$ & & \\
\hline$\geq 70 \mathrm{~d}$ & $10.3(2,112)$ & $1.40^{\mathrm{c}}$ & $1.16,1.70$ & \\
\hline $\begin{array}{l}\text { Percentage of days in the dry- } \\
\text { period with THI } \geq 72\end{array}$ & & & & $<0.001$ \\
\hline$<35 \%$ & $8.5(12,896)$ & 0.74 & $0.65,0.85$ & \\
\hline$\geq 35 \%$ & $11.7(3,208)$ & Referent & & \\
\hline
\end{tabular}




\begin{tabular}{|c|c|c|c|c|}
\hline Independent variables & Incidence & $\begin{array}{l}\text { Odds } \\
\text { ratio }\end{array}$ & $95 \% \mathrm{CI}$ & $P$-value \\
\hline Body condition score change & & & & $<0.001$ \\
\hline ELBCS & $8.1(1,604)$ & $1.63^{\mathrm{a}}$ & $1.26,2.09$ & \\
\hline MLBCS & $8.4(6,430)$ & $1.51^{\mathrm{a}}$ & $1.26,1.81$ & \\
\hline NCBCS & $7.6(4,819)$ & $1.38^{\mathrm{a}}$ & $1.14,1.66$ & \\
\hline GBCS & $5.9(3,251)$ & Referent $^{\mathrm{b}}$ & & \\
\hline Dairy & & & & $<0.001$ \\
\hline A & $10.7(5,263)$ & 1.95 & $1.70,2.23$ & \\
\hline B & $6.1(10,841)$ & Referent & & \\
\hline Parity & & & & $<0.001$ \\
\hline Primiparous & $4.6(8,161)$ & 0.41 & $0.36,0.47$ & \\
\hline Multiparous & $10.8(7,943)$ & Referent & & \\
\hline Calf sex & & & & $<0.001$ \\
\hline Female & $6.4(7,530)$ & 0.78 & $0.69,0.89$ & \\
\hline Male & $8.8(8,154)$ & Referent & & \\
\hline Number of calves born & & & & $<0.001$ \\
\hline Singleton & $6.7(14,665)$ & 0.36 & $0.30,0.43$ & \\
\hline Twins & $21.5(1,019)$ & Referent & & \\
\hline Gestation length & & & & $<0.001$ \\
\hline$\leq 273 \mathrm{~d}$ & $13.1(2,335)$ & $1.41^{\mathrm{a}}$ & $1.19,1.67$ & \\
\hline $274-283 \mathrm{~d}$ & $6.7(11,123)$ & Referent $^{\mathrm{b}}$ & & \\
\hline$\geq 284 \mathrm{~d}$ & $6.9(2,646)$ & $0.89^{\mathrm{b}}$ & $0.74,1.08$ & \\
\hline Length of the dry-period & & & & $<0.001$ \\
\hline$\leq 47 \mathrm{~d}$ & $10.1(2,515)$ & $1.97^{\mathrm{a}}$ & $1.64,2.38$ & \\
\hline $48-69 d$ & $6.2(11,477)$ & Referent $^{\mathrm{b}}$ & & \\
\hline$\geq 70 \mathrm{~d}$ & $12.8(2,112)$ & $1.87^{\mathrm{c}}$ & $1.58,2.21$ & \\
\hline
\end{tabular}

The interaction between $\triangle \mathrm{BCS}$ and dry-period length was $(\mathrm{P}=0.001)$ associated with the likelihood of culling within $60 \mathrm{~d}$ postpartum. Cows with ELBCS and GBCS and SDP were less likely to be culled than MLBCS and NCBCS cows with SDP (ELBCS $=1.5 \%$, MLBCS $=$ $4.9 \%, \mathrm{NCBCS}=5.5 \%, \mathrm{GBCS}=2.2 \%$ ). Among cows with LDP, GBCS cows were less likely to be culled than ELBCS, MLBCS, and NCBCS cows $(\mathrm{ELBCS}=10.8 \%$, MLBCS $=11.1 \%$, $\mathrm{NCBCS}=8.7 \%, \mathrm{GBCS}=5.7 \%)$. Among cows with NDP, those with ELBCS were less likely to be culled within $60 \mathrm{~d}$ postpartum than MLBCS, NCBCS, and GBCS cows (ELBCS $=2.0 \%$, MLBCS $=4.6 \%, \mathrm{NCBCS}=5.5 \%, \mathrm{GBCS}=4.4 \%)$. Cows from dairy A were $(\mathrm{P}<0.001)$ more likely to be culled within $60 \mathrm{~d}$ postpartum than cows from dairy $\mathrm{B}(\mathrm{AOR}=1.32,95 \% \mathrm{CI}=$ $1.13,1.54)$. Primiparous cows were $(\mathrm{P}<0.001)$ less likely to be culled within $60 \mathrm{~d}$ postpartum than multiparous cows $(\mathrm{AOR}=0.43,95 \% \mathrm{CI}=0.36,0.50)$. Cows that delivered singletons were $(\mathrm{AOR}=0.54,95 \% \mathrm{CI}=0.43,0.68 ; \mathrm{P}<0.001)$ less likely to be culled within $60 \mathrm{~d}$ postpartum. Gestation length was $(\mathrm{P}=0.001)$ associated with the likelihood of culling within $60 \mathrm{~d}$ 
postpartum because cows with SGL $(\mathrm{AOR}=1.47,95 \% \mathrm{CI}=1.20,1.81)$ were more likely to be culled within $60 \mathrm{~d}$ postparptum than cows with NGL (referent) and LGL (AOR $=1.01,95 \% \mathrm{CI}$ $=0.82,1.24)$.

The interactions between $\triangle \mathrm{BCS}$ and parity $(\mathrm{P}=0.008$; Figure 4$)$ and between $\triangle \mathrm{BCS}$ and length of the dry-period $(\mathrm{P}<0.001$; Figure 5) were associated with the hazard of removal from the herd up to 305 DIM. Cows that had ELBCS had $(\mathrm{AHR}=0.30,95 \% \mathrm{CI}=0.21,0.42$; $\mathrm{P}<0.001)$ reduced hazard of removal than GBCS cows. Cows that had NCBCS, however, had $(\mathrm{AHR}=1.44,95 \% \mathrm{CI}=1.26,1.66 ; \mathrm{P}<0.001)$ greater hazard of removal than GBCS cows. No difference in hazard of removal was observed between $\operatorname{MLBCS}(\mathrm{AHR}=1.05,95 \% \mathrm{CI}=0.91$, $1.20 ; \mathrm{P}=0.51)$ and GBCS cows. The mean interval from calving to removal from the herd were $292.5 \pm 1.3,273.6 \pm 1.0,264.5 \pm 1.2,277.1 \pm 1.3 \mathrm{~d}$ for ELBCS, MLBCS, NCBCS, and GBCS cows, respectively. The percentages of cows censored by 305 DIM were 92.8, 79.5, 72.4, and 80.9\% for ELBCS, MLBCS, NCBCS, and GBCS cows, respectively. Cows that delivered singletons had $(\mathrm{AHR}=0.80,95 \% \mathrm{CI}=0.70,0.90 ; \mathrm{P}<0.001)$ reduced hazard of removal from the herd up to 305 DIM than cows that delivered twins. There was $(\mathrm{P}<0.001)$ an association between length of gestation and hazard of removal from the herd up to 305 DIM because cows with SGL had $(\mathrm{AHR}=1.24,95 \% \mathrm{CI}=1.12,1.38)$ greater hazard of removal than NGL (referent) and LGL (AHR $=0.932,95 \% \mathrm{CI}=0.84,1.03)$ cows, which did not differ.

Figure 4 - Survival analysis of the interval from parturition to removal from the herd according to body condition score change during the dry-period $(\triangle \mathrm{BCS})$ and parity. Test of equality Wilcoxon: Mean $( \pm$ SEM) days to removal for primiparous cows $(\mathrm{P}<0.001)-$ ELBCS $(\triangle \mathrm{BCS} \leq-0.75)=299.5 \pm 1.1, \operatorname{MLBCS}(\triangle \mathrm{BCS}=-0.5$ to -0.25$)=283.7 \pm 1.1, \mathrm{NCBCS}$ $(\triangle \mathrm{BCS}=0)=274.5 \pm 1.5$, and GBCS $(\triangle \mathrm{BCS} \geq 0.25)=286.1 \pm 1.5 \mathrm{~d}$; mean $( \pm \mathrm{SEM})$ days to removal for multiparous cows $(\mathrm{P}<0.001)-\mathrm{ELBCS}=273.5 \pm 2.8, \mathrm{MLBCS}=262.6 \pm$ $1.6, \mathrm{NCBCS}=254.9 \pm 1.8$, and $\mathrm{GBCS}=269.9 \pm 1.9 \mathrm{~d}$.
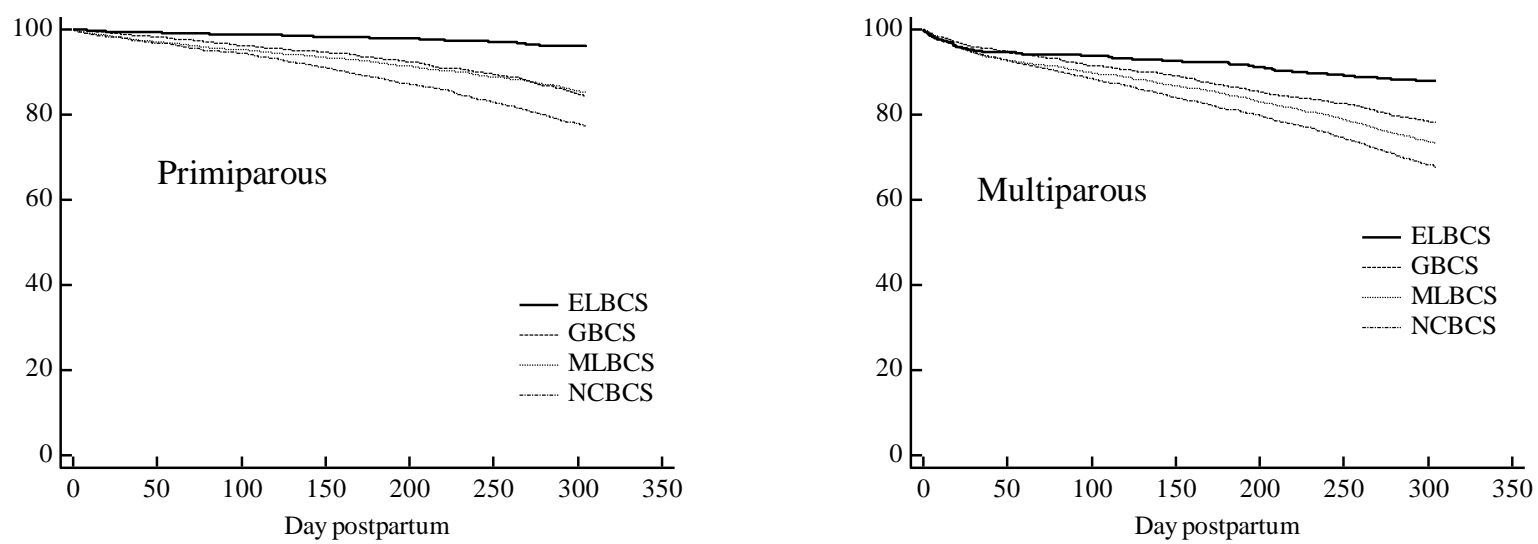
Figure 5 - Survival analysis of the interval from parturition to removal from the herd according to body condition score change during the dry-period $(\triangle \mathrm{BCS})$ and length of the dry-period. Test of equality Wilcoxon: Mean $( \pm$ SEM) days to removal for cows with short dry-period $(\mathrm{SDP} ; \mathrm{P}<0.001)-\mathrm{ELBCS}(\triangle \mathrm{BCS} \leq-0.75)=297.1 \pm 2.0, \operatorname{MLBCS}(\triangle \mathrm{BCS}=-0.5$ to -0.25$)$ $=268.7 \pm 2.3$, NCBCS $(\triangle \mathrm{BCS}=0)=258.8 \pm 3.4$, and $\mathrm{GBCS}(\triangle \mathrm{BCS} \geq 0.25)=277.8 \pm 3.5$ $\mathrm{d}$; mean $( \pm$ SEM) days to removal for cows with normal dry-period (NDP; P $<0.001$ ) $\mathrm{ELBCS}=291.7 \pm 1.4, \mathrm{MLBCS}=278.4 \pm 1.1, \mathrm{NCBCS}=266.7 \pm 1.3$, and $\mathrm{GBCS}=277.2$ $\pm 1.4 \mathrm{~d}$; mean $( \pm$ SEM) days to removal for cows with long dry-period (LDP; $\mathrm{P}<0.001)-$ $\mathrm{ELBCS}=235.1 \pm 7.1, \mathrm{MLBCS}=250.1 \pm 3.4, \mathrm{NCBCS}=254.3 \pm 3.6$, and $\mathrm{GBCS}=273.8$ \pm 3.5 .
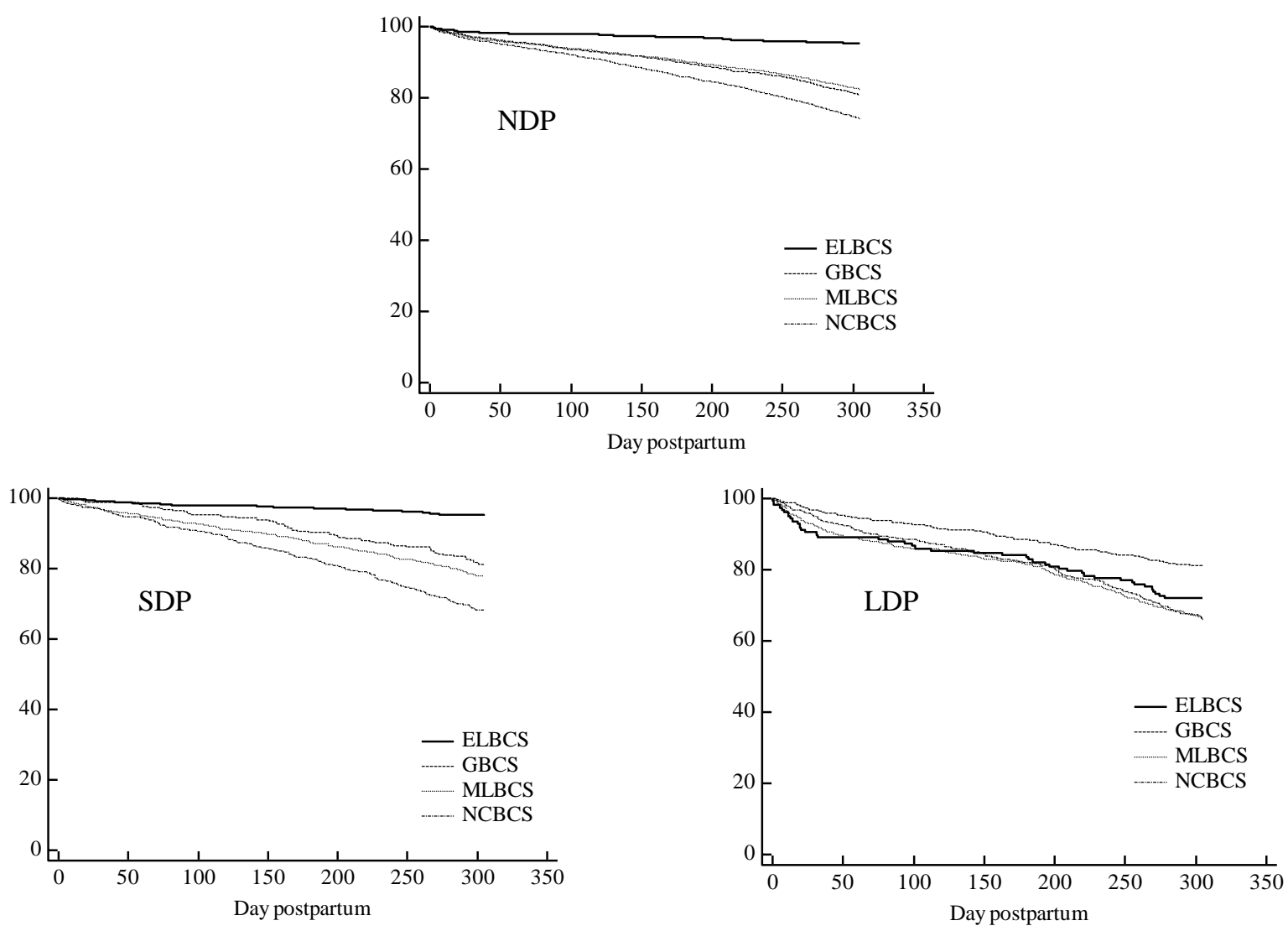


\subsubsection{Association between $\triangle B C S$ and Reproductive Parameters}

The likelihood of cows receiving the first postpartum AI upon detected estrus $(\mathrm{P}=0.22)$ and the DIM at first postpartum AI $(\mathrm{P}=0.48)$ were not associated with $\triangle \mathrm{BCS}$. Body condition score change during the dry-period was $(\mathrm{P}<0.001)$ associated with the likelihood of pregnancy $35 \pm 7 \mathrm{~d}$ after the first postpartum AI. Cows with ELBCS (AOR $=0.41,95 \% \mathrm{CI}=0.36,0.47)$, $\operatorname{MLBCS}(\mathrm{AOR}=0.59,95 \% \mathrm{CI}=0.54,0.65)$, and $\mathrm{NCBCS}(\mathrm{AOR}=0.71,95 \% \mathrm{CI}=0.64,0.78)$ were less likely to be pregnant $35 \pm 7 \mathrm{~d}$ after the first postpartum AI than GBCS cows. Primiparous cows were $(\mathrm{AOR}=1.14,95 \% \mathrm{CI}=1.07,1.23 ; \mathrm{P}<0.001)$ more likely to be pregnant $35 \pm 7 \mathrm{~d}$ after the first postpartum AI than multiparous cows. Cows that delivered singletons calves were $(\mathrm{AOR}=1.23,95 \% \mathrm{CI}=1.05,1.43 ; \mathrm{P}=0.009)$ more likely to be pregnant $35 \pm 7 \mathrm{~d}$ after the first postpartum AI than cows that delivered twin calves. Cows not exposed to heat stress during the dry-period were $(\mathrm{AOR}=1.25,95 \% \mathrm{CI}=1.14,1.37 ; \mathrm{P}<0.001)$ more likely to be pregnant $35 \pm 7 \mathrm{~d}$ after the first postpartum AI than cows exposed to heat stress.

Change in BCS during the dry-period was $(\mathrm{P}<0.001)$ associated with the likelihood of pregnancy $67 \pm 3 \mathrm{~d}$ after the first postpartum AI (Table 6). Primiparous cows were $(\mathrm{P}<0.001)$ more likely to be pregnant $67 \pm 3 \mathrm{~d}$ after the first postpartum AI than multiparous cows (Table 6). Cows that delivered singletons were $(P=0.005)$ more likely to be pregnant $67 \pm 3 \mathrm{~d}$ after the first postpartum AI than cows that delivered twin calves (Table 6). Cows not exposed to heat stress during the dry-period were $(\mathrm{P}<0.001)$ more likely to be pregnant $67 \pm 3 \mathrm{~d}$ after the first postpartum AI than cows exposed to heat stress (Table 6).

The interaction between $\triangle \mathrm{BCS}$ and parity tended $(\mathrm{P}=0.02)$ to be associated with pregnancy loss from $35 \pm 7$ to $67 \pm 3 \mathrm{~d}$ after the first postpartum AI. Among primiparous cows, pregnancy loss was 18.6, 11.0, 6.2, and 4.7\% for ELBCS, MLBCS, NCBCS, and GBCS cows, respectively, whereas among multiparous cows pregnancy loss was 10.2, 9.9, 8.6, and $4.3 \%$ for ELBCS, MLBCS, NCBCS, and GBCS cows, respectively. Additionally, there was a tendency $(\mathrm{P}=0.05)$ for the interaction between $\triangle \mathrm{BCS}$ and length of the dry-period to be associated with pregnancy loss from $35 \pm 7$ to $67 \pm 3 \mathrm{~d}$ after the first postpartum AI. Among cows with SDP, pregnancy loss was 16.4, 6.7, 8.3, and 6.5\% for ELBCS, MLBCS, NCBCS, and GBCS cows, respectively. Pregnancy loss was 10.3, 13.9, 4.6, and 3.6\% for ELBCS, MLBCS, NCBCS, and GBCS cows with LDP, respectively. Finally, among cows with NDP pregnancy loss was 15.8, 11.0, 7.7, and 4.4\% for ELBCS, MLBCS, NCBCS, and GBCS cows. 


\begin{tabular}{|c|c|c|c|c|}
\hline Independent variables & $\mathrm{P} / \mathrm{AI}^{*}$ & $\begin{array}{l}\text { Odds } \\
\text { ratio }\end{array}$ & $95 \% \mathrm{CI}$ & $P$ - value \\
\hline Body condition score change & & & & $<0.001$ \\
\hline ELBCS & $20.8(1,540)$ & $0.36^{\mathrm{a}}$ & $0.31,0.41$ & \\
\hline MLBCS & $28.3(5,812)$ & $0.55^{\mathrm{b}}$ & $0.50,0.60$ & \\
\hline NCBCS & $33.1(4,258)$ & $0.68^{\mathrm{c}}$ & $0.62,0.75$ & \\
\hline GBCS & $41.9(2,955)$ & Referent $^{\mathrm{d}}$ & & \\
\hline Parity & & & & $<0.001$ \\
\hline Primiparous & $32.4(7,711)$ & 1.13 & $1.05,1.22$ & \\
\hline Multiparous & $30.9(6,854)$ & Referent & & \\
\hline Number of calves born & & & & 0.005 \\
\hline Singleton & $32.3(13,298)$ & 1.26 & $1.07,1.48$ & \\
\hline Twins & $25.2(882)$ & Referent & & \\
\hline $\begin{array}{l}\text { Percentage of days in the dry- } \\
\text { period with } \mathrm{THI} \geq 72\end{array}$ & & & & $<0.001$ \\
\hline$<35 \%$ & $32.7(11,676)$ & 1.26 & $1.15,1.39$ & \\
\hline$\geq 35 \%$ & $27.5(2,889)$ & Referent & & \\
\hline
\end{tabular}

The interaction between $\triangle \mathrm{BCS}$ and parity tended $(\mathrm{P}=0.04)$ to be associated with the likelihood of pregnancy $35 \pm 7 \mathrm{~d}$ after the second postpartum. Among primiparous cows, P/AI was 23.4, 31.3, 33.3, and 40.7\% for ELBCS, MLBCS, NCBCS, and GBCS cows, respectively. The P/AI among multiparous cows was 27.3, 27.2, 28.4, and 35.9\% for ELBCS, MLBCS, NCBCS, and GBCS cows, respectively. The likelihood of pregnancy at $35 \pm 7 \mathrm{~d}$ after the second postpartum $\mathrm{AI}$ was $(\mathrm{P}=0.01)$ associated with the interaction between $\triangle \mathrm{BCS}$ and exposure to heat stress during the dry-period. Among cows not exposed to heat stress, the P/AI was 24.9, 30.2, 31.0, and 36.4\% for ELBCS, MLBCS, NCBCS, and GBCS cows, respectively. Among cows exposed to heat stress, the P/AI was 24.5, 26.7, 30.3, and 44.7\% for ELBCS, MLBCS, NCBCS, and GBCS cows, respectively. There was a tendency $(\mathrm{P}=0.02)$ for gestation length to be associated with the likelihood of pregnancy $35 \pm 7 \mathrm{~d}$ after the second postpartum AI because $\mathrm{LGL}$ cows were $(\mathrm{AOR}=0.84,95 \% \mathrm{CI}=0.74,0.96)$ less likely to be pregnant than cows with normal (referent) and short $(\mathrm{AOR}=0.89,95 \% \mathrm{CI}=0.77,1.02)$ gestation length. Length of the dry-period was $(\mathrm{P}<0.001)$ associated with the likelihood of pregnancy $35 \pm 7 \mathrm{~d}$ after the second postpartum AI because SDP cows tended to be $(\mathrm{AOR}=1.17,95 \% \mathrm{CI}=1.03$, $1.34 ; \mathrm{P}=0.02$ ) more likely to be pregnant $35 \pm 7 \mathrm{~d}$ after the second postpartum AI than NDP cows (referent), whereas LDP cows were $(\mathrm{AOR}=0.80,95 \% \mathrm{CI}=0.69,0.93 ; \mathrm{P}=0.004)$ less likely to be pregnant $35 \pm 7 \mathrm{~d}$ after the second postpartum AI than NDP cows. 
The interaction between $\triangle \mathrm{BCS}$ and parity tended $(\mathrm{P}=0.02)$ to be associated with the likelihood of pregnancy $67 \pm 3 \mathrm{~d}$ after the second postpartum. Among primiparous cows, the P/AI was 20.4, 28.4, 31.2, and 38.8\% for ELBCS, MLBCS, NCBCS, and GBCS cows, respectively. The P/AI among multiparous cows was 25.0, 24.9, 26.6, and 34.4\% for ELBCS, MLBCS, NCBCS, and GBCS cows, respectively. There was a tendency $(\mathrm{P}=0.02)$ for the interaction between $\triangle \mathrm{BCS}$ and exposure to heat stress during the dry-period to be associated with the likelihood of pregnancy at $67 \pm 3$ after the second postpartum AI. Among cows not exposed to heat stress the P/AI was 21.9, 27.5, 29.2, and 34.9\% for ELBCS, MLBCS, NCBCS, and GBCS cows, respectively. Among cows exposed to heat stress, the P/AI was 22.8, 24.3, 28.0, and $42.3 \%$ for ELBCS, MLBCS, NCBCS, and GBCS cows, respectively. There was a tendency $(\mathrm{P}=0.02)$ for gestation length to be associated with the likelihood of pregnancy $67 \pm$ $3 \mathrm{~d}$ after the second postpartum AI. Cows with $\mathrm{LGL}$ were $(\mathrm{AOR}=0.84,95 \% \mathrm{CI}=0.74,0.96)$ less likely to be pregnant than NGL (referent) and SGL (AOR $=0.89,95 \% \mathrm{CI}=0.77,1.03$ ) cows. Length of the dry-period was $(\mathrm{P}<0.001)$ associated with the likelihood of pregnancy at $67 \pm 3 \mathrm{~d}$ after the second postpartum AI. Cows with $\mathrm{SDP}$ were $(\mathrm{AOR}=1.20,95 \% \mathrm{CI}=1.05$, 1.38; $\mathrm{P}=0.008$ ) more likely to be pregnant than NDP cows (referent), whereas LDP cows were $(\mathrm{AOR}=0.81,95 \% \mathrm{CI}=0.70,0.95 ; \mathrm{P}=0.009)$ less likely to be pregnant than NDP cows.

Change in BCS during the period was $(\mathrm{P}<0.001)$ associated with the likelihood of pregnancy loss between $35 \pm 7$ and $67 \pm 3 \mathrm{~d}$ after the second postpartum AI. Cows with ELBCS $(\mathrm{AOR}=2.53,95 \% \mathrm{CI}=1.49,4.29)$ were more likely to have pregnancy loss than NCBCS $(\mathrm{AOR}=1.41,95 \% \mathrm{CI}=0.88,2.28)$ and GBCS (referent) cows, whereas cows with MLBCS $(\mathrm{AOR}=2.02,95 \% \mathrm{CI}=1.31,3.11)$ were more likely to have pregnancy loss than GBCS cows. There was a tendency $(P=0.05)$ for cows that delivered singletons to be less $(A O R=0.61$, $95 \% \mathrm{CI}=0.37,1.00$ ) likely to have pregnancy loss between $35 \pm 7$ and $67 \pm 3 \mathrm{~d}$ after the second postpartum AI than cows that delivered twins.

The interactions between $\triangle \mathrm{BCS}$ and dairy $(\mathrm{P}<0.001$; Figure 6$)$ and between $\triangle \mathrm{BCS}$ and parity ( $\mathrm{P}=0.01$; Figure 7 ) were associated with the hazard of pregnancy up to 305 DIM. Cows with ELBCS tended to $(\mathrm{P}=0.03)$ and cows with MLBCS and NCBCS had $(\mathrm{P}<0.001)$ reduced hazard of pregnancy than GBCS cows (Table 7). Cows that delivered singletons had ( $\mathrm{P}<0.001)$ greater hazard of pregnancy than cows that delivered twins (Table 7). Gestation length was (P $=0.002$ ) associated with the hazard of pregnancy because SGL and LGL cows had reduced hazard of pregnancy compared with NGL cows (Table 7). Length of the dry period was (P < 0.001) was associated with hazard of pregnancy because SDP cows had greater hazard of pregnancy than NDP cows, whereas LDP cows had reduced hazard of pregnancy than NDP 
cows (Table 7). Finally, cows not exposed to heat stress during the dry-period tended $(\mathrm{P}=0.03)$ to have greater hazard of pregnancy than cows exposed to heat stress during the dry-period (Table 7).

Figure 6 - Survival analysis of the interval from parturition to pregnancy according to body condition score change during the dry-period $(\triangle \mathrm{BCS})$ and dairy. Association between $\triangle \mathrm{BCS}$ and the interval from parturition to pregnancy according to the test of equality Wilcoxon: Mean $( \pm$ SEM $)$ days to pregnancy for cows from dairy A $(\mathrm{P}<0.001)-\operatorname{ELBCS}(\triangle \mathrm{BCS} \leq-0.75)=$ $199.9 \pm 6.9 \mathrm{~d}$, MLBCS $(\triangle \mathrm{BCS}=-0.5$ to -0.25$)=161.2 \pm 2.2 \mathrm{~d}, \operatorname{NCBCS}(\triangle \mathrm{BCS}=0)=$ $153.5 \pm 2.3 \mathrm{~d}$, and $\mathrm{GBCS}(\triangle \mathrm{BCS} \geq 0.25)=133.2 \pm 2.3 \mathrm{~d}$; mean $( \pm \mathrm{SEM})$ days to pregnancy for cows from dairy $\mathrm{B}(\mathrm{P}<0.001)-$ ELBCS $=160.4 \pm 2.1 \mathrm{~d}$, MLBCS $=157.2 \pm 1.4 \mathrm{~d}$, $\mathrm{NCBCS}=159.2 \pm 1.9 \mathrm{~d}$, and $\mathrm{GBCS}=136.3 \pm 2.3 \mathrm{~d}$.
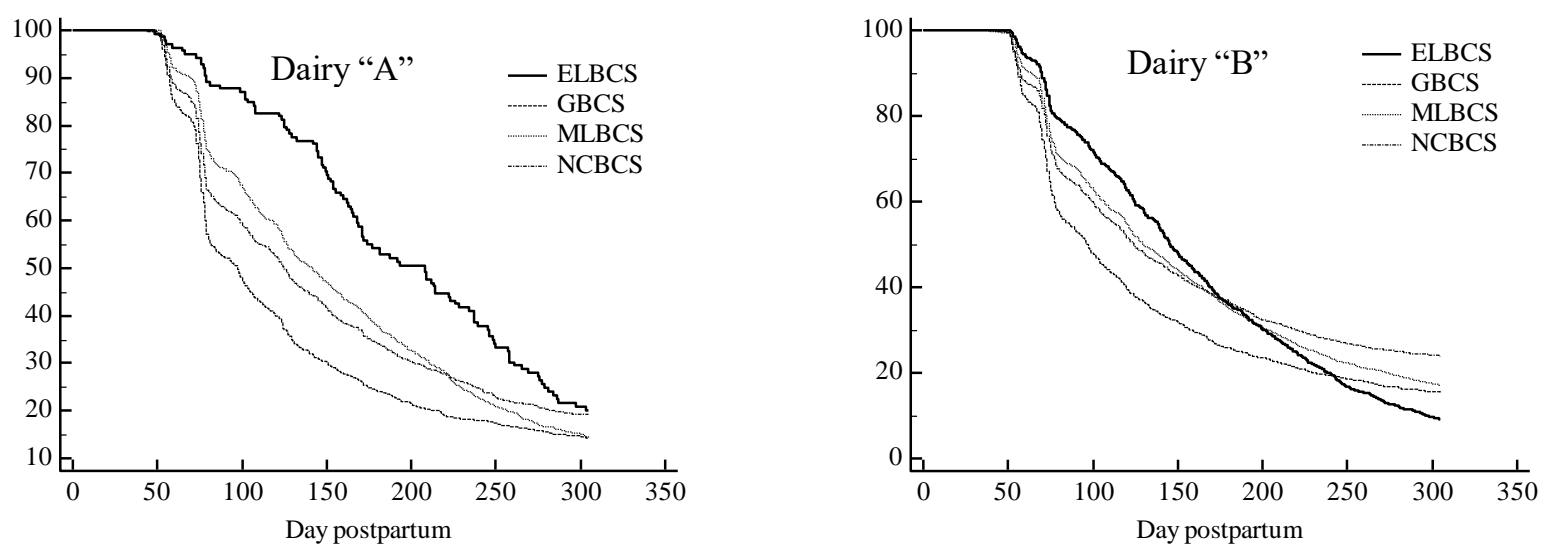

Figure 7 - Survival analysis of the interval from parturition to pregnancy according to body condition score change during the dry-period $(\triangle \mathrm{BCS})$ and parity. Association between $\triangle \mathrm{BCS}$ and the interval from parturition to pregnancy according to the test of equality Wilcoxon: Mean $( \pm$ SEM) days to pregnancy for primiparous $(\mathrm{P}<0.001)-\mathrm{ELBCS}(\triangle \mathrm{BCS} \leq-0.75)=166.3$ $\pm 2.5 \mathrm{~d}$, MLBCS $(\triangle \mathrm{BCS}=-0.5$ to -0.25$)=153.2 \pm 1.5 \mathrm{~d}$, NCBCS $(\triangle \mathrm{BCS}=0)=151.2 \pm$ $2.0 \mathrm{~d}$, and $\mathrm{GBCS}(\triangle \mathrm{BCS} \geq 0.25)=130.5 \pm 2.4 \mathrm{~d}$; mean $( \pm \mathrm{SEM})$ days to pregnancy for multiparous $(\mathrm{P}<0.001)-\mathrm{ELBCS}=159.6 \pm 3.4 \mathrm{~d}$, MLBCS $=164.4 \pm 1.8 \mathrm{~d}, \mathrm{NCBCS}=$ $163.8 \pm 2.1 \mathrm{~d}$, and GBCS $=138.8 \pm 2.2 \mathrm{~d}$.
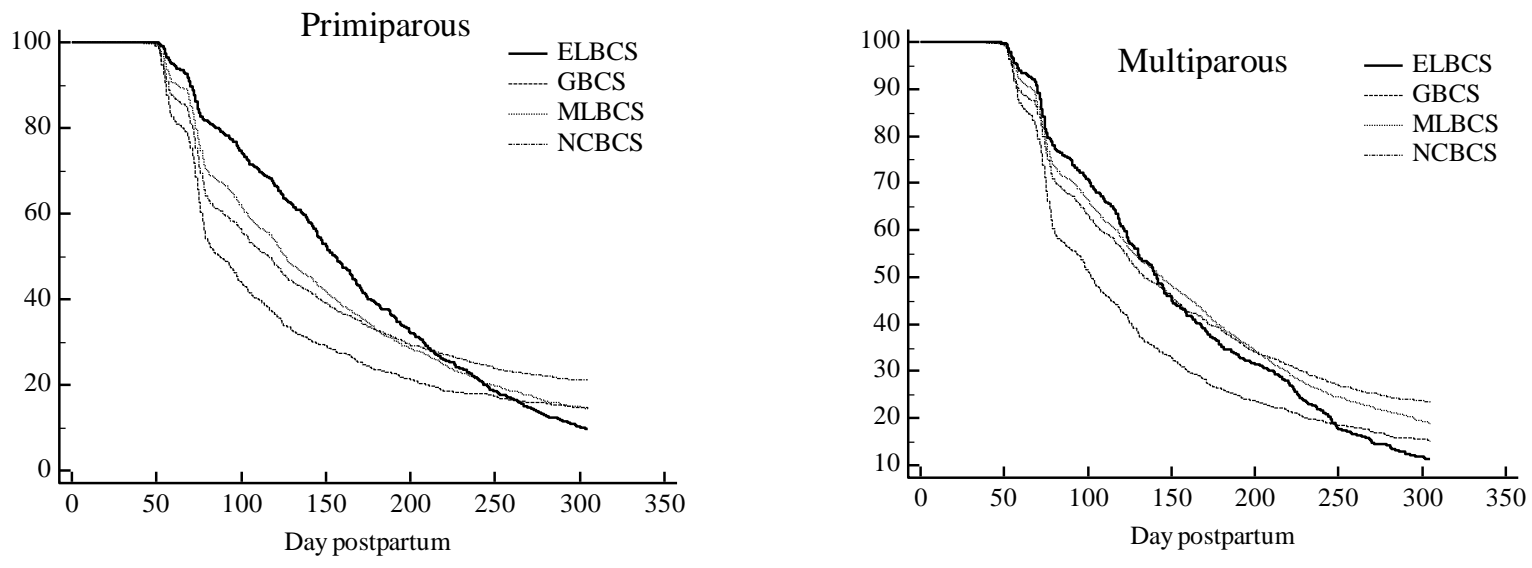


\subsubsection{Association between $\triangle \mathrm{BCS}$ and Productive Parameters}

The interaction between $\triangle \mathrm{BCS}$ and month of lactation was $(\mathrm{P}<0.001)$ associated with milk yield (Figure 8A). Mean daily milk yield over $305 \mathrm{~d}$ was highest for GBCS cows (40.60 $\pm 0.11 \mathrm{~kg} / \mathrm{d})$, followed by NCBCS cows $(39.58 \pm 0.10 \mathrm{~kg} / \mathrm{d})$ and MLBCS $(39.20 \pm 0.09 \mathrm{~kg} / \mathrm{d})$ and ELBCS $(39.28 \pm 0.15 \mathrm{~kg} / \mathrm{d})$ cows, which did not differ. Cows from dairy A had $(\mathrm{P}<0.001)$ greater milk yield than cows from dairy B $(39.91 \pm 0.12$ vs. $39.42 \pm 0.10 \mathrm{~kg} / \mathrm{d})$. Multiparous cows had $(\mathrm{P}<0.001)$ greater milk yield than primiparous cows $(40.19 \pm 0.09$ vs. $39.14 \pm 0.09$ $\mathrm{kg} / \mathrm{d})$. Cows that delivered twins had $(\mathrm{P}<0.001)$ lower milk yield than cows that delivered singletons $(38.56 \pm 0.16$ vs. $39.10 \pm 0.09 \mathrm{~kg} / \mathrm{d})$. Cows with $\mathrm{SGL}(38.37 \pm 0.12 \mathrm{~kg} / \mathrm{d})$ had $(\mathrm{P}<$ $0.001)$ the lowest milk yield followed by NGL $(40.11 \pm 0.08 \mathrm{~kg} / \mathrm{d})$ and LGL $(40.52 \pm 0.12 \mathrm{~kg} / \mathrm{d})$ cows. Cows with SDP $(36.85 \pm 0.15 \mathrm{~kg} / \mathrm{d})$ had $(\mathrm{P}<0.001)$ the lowest milk yield followed by cows with NDP $(39.84 \pm 0.11 \mathrm{~kg} / \mathrm{d})$ and LDP $(39.79 \pm 0.14 \mathrm{~kg} / \mathrm{d})$. Cows exposed to heat stress during the dry-period had $(\mathrm{P}<0.001)$ reduced milk yield than cows not exposed to heat stress $(38.41 \pm 0.13$ vs. $39.24 \pm 0.11 \mathrm{~kg} / \mathrm{d})$.

\begin{tabular}{|c|c|c|c|c|}
\hline Independent variables & Censored, \% (n) & $\begin{array}{l}\text { Hazard } \\
\text { ratio }\end{array}$ & $95 \% \mathrm{CI}$ & $P$ - value \\
\hline$\triangle \mathrm{BCS}^{* \neq}$ & & & & $<0.001$ \\
\hline ELBCS & $14.7(1,604)$ & $0.88^{\mathrm{a}}$ & $0.79,0.99$ & \\
\hline MLBCS & $26.9(6,430)$ & $0.76^{\mathrm{b}}$ & $0.70,0.83$ & \\
\hline NCBCS & $33.7(4,819)$ & $0.70^{\mathrm{b}}$ & $0.64,0.77$ & \\
\hline GBCS & $24.1(3,251)$ & Referent $^{\mathrm{c}}$ & & \\
\hline Number of calves born & & & & $<0.001$ \\
\hline Singleton & $26.3(14,665)$ & 1.24 & $1.14,1.35$ & \\
\hline Twins & $37.4(1,019)$ & Referent & & \\
\hline Gestation length & & & & 0.002 \\
\hline$\leq 273 \mathrm{~d}$ & $31.7(2,335)$ & $0.93^{\mathrm{a}}$ & $0.87,0.98$ & \\
\hline $274-283 \mathrm{~d}$ & $25.6(10,314)$ & Referent $^{\mathrm{b}}$ & & \\
\hline$\geq 284 \mathrm{~d}$ & $28.6(3,455)$ & $0.93^{\mathrm{a}}$ & $0.88,0.98$ & \\
\hline Length of the dry-period & & & & $<0.001$ \\
\hline$\leq 47 \mathrm{~d}$ & $24.7(2,515)$ & $1.08^{\mathrm{a}}$ & $1.02,1.15$ & \\
\hline $48-69 d$ & $26.0(11,477)$ & Referent $^{\mathrm{b}}$ & & \\
\hline$\geq 70 \mathrm{~d}$ & $36.6(2,112)$ & $0.91^{\mathrm{c}}$ & $0.85,0.97$ & \\
\hline $\begin{array}{l}\text { Percentage of days in the dry- } \\
\text { period with THI } \geq 72\end{array}$ & & & & 0.03 \\
\hline$<35 \%$ & $26.9(12,896)$ & 1.05 & $1.01,1.10$ & \\
\hline$\geq 35 \%$ & $28.0(3,208)$ & Referent & & \\
\hline
\end{tabular}

${ }^{*} \triangle \mathrm{BCS}$ : body condition score change during the dry-period

Interactions: $\triangle \mathrm{BCS}$ x Dairy $(P<0.001) ; \triangle \mathrm{BCS}$ x Parity $(P=0.01)$

a,b,c Within parameter, rows with different superscripts differ $(P \leq 0.01)$ 
There was $(\mathrm{P}<0.001)$ an association between $\triangle \mathrm{BCS}$ and fat yield because GBCS cows $(1.50 \pm 0.01 \mathrm{~kg} / \mathrm{d})$ had the highest fat yield followed by NCBCS $(1.45 \pm 0.01 \mathrm{~kg} / \mathrm{d})$, MLBCS $(1.42 \pm 0.01 \mathrm{~kg} / \mathrm{d})$, and ELBCS $(1.40 \pm 0.01 \mathrm{~kg} / \mathrm{d})$ cows. Cows from dairy A had $(\mathrm{P}<0.01)$ lower fat yield than cows from dairy B $(1.41 \pm 0.01$ vs. $1.48 \pm 0.01 \mathrm{~kg} / \mathrm{d})$. Primiparous cows had $(\mathrm{P}=0.01)$ lower fat yield than multiparous cows $(1.44 \pm 0.01$ vs. $1.45 \pm 0.01)$. Cows that delivered singletons had $(\mathrm{P}<0.001)$ greater fat yield than cows that delivered twins $(1.43 \pm$ 0.01 vs. $1.39 \pm 0.01 \mathrm{~kg} / \mathrm{d})$. There was $(\mathrm{P}<0.001)$ an association between gestation length and fat yield because cows with SGL $(1.40 \pm 0.01 \mathrm{~kg} / \mathrm{d})$ had the lowest fat yield followed by NGL $(1.45 \pm 0.01 \mathrm{~kg} / \mathrm{d})$ and LGL $(1.47 \pm 0.01 \mathrm{~kg} / \mathrm{d})$ cows, respectively. Similarly, cows with SDP $(1.35 \pm 0.01 \mathrm{~kg} / \mathrm{d})$ had $(\mathrm{P}<0.001)$ lower fat yield than NDP $(1.43 \pm 0.01 \mathrm{~kg} / \mathrm{d})$ and LDP $(1.44$ $\pm 0.01 \mathrm{~kg} / \mathrm{d})$ cows. Cows exposed to heat stress during the dry-period had $(\mathrm{P}=0.003)$ reduced fat yield compared with cows not exposed to heat stress $(1.40 \pm 0.01 \mathrm{vs} .1 .41 \pm 0.01 \mathrm{~kg} / \mathrm{d})$.

Cows that gained BCS during the dry-period had the greatest yield of 3.5\%-FCM (41.87 $\pm 0.16 \mathrm{~kg} / \mathrm{d})$, followed by NCBCS cows $(40.61 \pm 0.15 \mathrm{~kg} / \mathrm{d})$, MLBCS cows $(39.94 \pm 0.14 \mathrm{~kg} / \mathrm{d})$, and ELBCS cows $(39.30 \pm 0.29 \mathrm{~kg} / \mathrm{d})$. Cows from dairy A had $(\mathrm{P}<0.001)$ lower $3.5 \%$-FCM yield than cows from dairy B $(39.83 \pm 0.15$ vs. $41.03 \pm 0.17 \mathrm{~kg} / \mathrm{d})$. Primiparous cows had $(\mathrm{P}<$ $0.001)$ lower $3.5 \%$-FCM yield than multiparous cows $(40.25 \pm 0.14$ vs. $40.60 \pm 0.14 \mathrm{~kg} / \mathrm{d})$. Additionally, cows that delivered singletons had $(\mathrm{P}<0.001)$ greater $3.5 \%$-FCM yield than cows that delivered twins $(40.78 \pm 0.11$ vs. $40.08 \pm 0.21 \mathrm{~kg} / \mathrm{d})$. Gestation length was $(\mathrm{P}<0.001)$ associated with 3.5\%-FCM yield because cows with SGL had the smallest 3.5\%-FCM yield $(39.34 \pm 0.18 \mathrm{~kg} / \mathrm{d})$, followed by cows with NGL $(40.75 \pm 0.14 \mathrm{~kg} / \mathrm{d})$, and cows with LGL $(41.20 \pm 0.18 \mathrm{~kg} / \mathrm{d})$. Additionally, cows with SDP $(38.12 \pm 0.31 \mathrm{~kg} / \mathrm{d})$ had $(\mathrm{P}<0.001)$ the lowest $3.5 \%$-FCM yield followed by cows with NDP $(40.48 \pm 0.14 \mathrm{~kg} / \mathrm{d})$ and LDP $(40.47 \pm 0.19 \mathrm{~kg} / \mathrm{d})$. Cows exposed to heat stress during the dry-period had $(\mathrm{P}<0.001)$ reduced 3.5\%-FCM yield than cows not exposed to heat stress $(39.41 \pm 0.18$ vs. $39.96 \pm 0.16 \mathrm{~kg} / \mathrm{d})$.

The interaction between $\triangle \mathrm{BCS}$ and month of lactation tended $(\mathrm{P}=0.02)$ to be associated with protein yield (Figure 8B). Cows that gained BCS during the dry-period $(1.22 \pm 0.01 \mathrm{~kg} / \mathrm{d})$ had $(\mathrm{P}<0.001)$ greater protein yield than NCBCS $(1.19 \pm 0.01 \mathrm{~kg} / \mathrm{d})$, MLBCS $(1.18 \pm 0.01$ $\mathrm{kg} / \mathrm{d})$, and ELBCS $(1.18 \pm 0.01 \mathrm{~kg} / \mathrm{d})$ cows. 
Figure 8 - Association between change in BCS during the dry-period ( $\triangle \mathrm{BCS}$ ) and yield of milk (A) and protein (B). Milk yield ( \pm SEM; $\triangle \mathrm{BCS}-\mathrm{P}<0.001, \triangle \mathrm{BCS}$ x month postpartum $-\mathrm{P}<$ $0.001): \operatorname{ELBCS}(\triangle \mathrm{BCS} \leq-0.75)=39.28 \pm 0.15$, MLBCS $(\triangle \mathrm{BCS}=-0.5$ to -0.25$)=39.20$ \pm 0.09 , NCBCS $(\triangle \mathrm{BCS}=0)=39.58 \pm 0.10$, and GBCS $(\triangle \mathrm{BCS} \geq 0.25)=40.60 \pm 0.11$ $\mathrm{kg} / \mathrm{d}$. Protein yield $( \pm \mathrm{SEM} ; \triangle \mathrm{BCS}-\mathrm{P}<0.001, \triangle \mathrm{BCS} \times$ month postpartum $-\mathrm{P}=0.02)$ : ELBCS $=1.177 \pm 0.008$, MLBCS $=1.179 \pm 0.004$, NCBCS $=1.191 \pm 0.004$, and GBCS $=$ $1.217 \pm 0.004 \mathrm{~kg} / \mathrm{d}$.
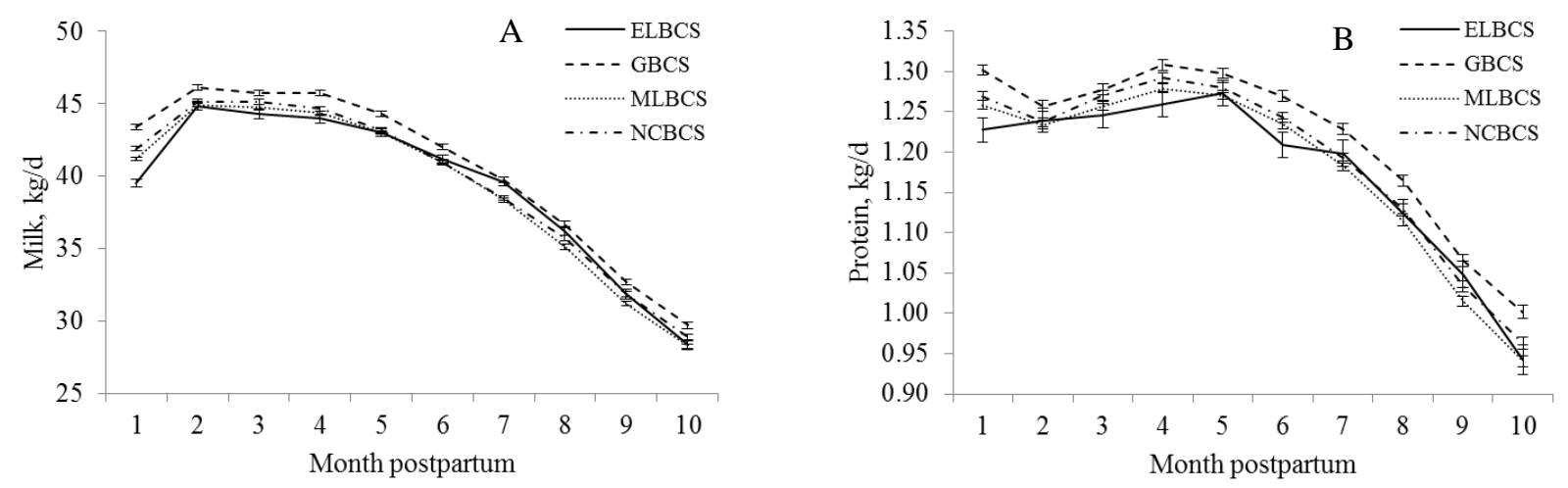

Cows from dairy A tended $(\mathrm{P}=0.03)$ to have lower protein yield than cows from dairy B $(1.19 \pm 0.01$ vs. $1.20 \pm 0.01 \mathrm{~kg} / \mathrm{d})$. Gestation length was $(\mathrm{P}<0.001)$ associated with protein yield because SGL cows $(1.17 \pm 0.01 \mathrm{~kg} / \mathrm{d})$ had $(\mathrm{P}<0.001)$ lower protein yield than NGL $(1.20$ $\pm 0.01 \mathrm{~kg} / \mathrm{d})$ and LGL $(1.21 \pm 0.01 \mathrm{~kg} / \mathrm{d})$ cows, which did not $(\mathrm{P}=0.18)$ differ. Length of the dry period was $(\mathrm{P}<0.001)$ associated with protein yield because SDP cows had $(\mathrm{P}<0.001)$ lower protein yield $(1.16 \pm 0.01 \mathrm{~kg} / \mathrm{d})$ than NDP $(1.20 \pm 0.01 \mathrm{~kg} / \mathrm{d})$ and LDP $(1.19 \pm 0.01)$ cows, whereas LDP cows tended $(\mathrm{P}=0.02)$ to have lower protein yield than NDP cows. Cows exposed to heat stress during the dry-period had $(\mathrm{P}=0.005)$ reduced protein yield than cows not exposed to heat stress during the dry-period $(1.19 \pm 0.01$ vs. $1.18 \pm 0.01)$.

Change in BCS during the dry-period was $(\mathrm{P}<0.001)$ associated with somatic cell linear score in the subsequent lactation $(\mathrm{ELBCS}=3.55 \pm 0.06, \mathrm{MLBCS}=3.52 \pm 0.03, \mathrm{NCBCS}=3.43$ \pm 0.03 , and GBCS $=3.35 \pm 0.03)$. Cows with ELBCS tended to have $(\mathrm{P}=0.03)$ and had $(\mathrm{P}<$ $0.001)$ greater somatic cell linear score than NCBCS and GBCS cows, respectively, but did not $(\mathrm{P}=0.62)$ differ from MLBCS cows. Somatic cell linear score of cows with MLBCS $(\mathrm{P}<$ $0.001)$ and NCBCS $(P=0.005)$ were greater than the somatic cell linear score of GBCS cows. Somatic cell linear score within $60 \mathrm{~d}$ prior to dry-off was $(\mathrm{P}<0.001)$ associated with $\triangle \mathrm{BCS}$ $(\mathrm{ELBCS}=3.06 \pm 0.06, \mathrm{MLBCS}=3.45 \pm 0.03, \mathrm{NCBCS}=3.60 \pm 0.03, \mathrm{GBCS}=3.47 \pm 0.03)$ because ELBCS cows had $(\mathrm{P}<0.001)$ lower somatic cell linear score than MLBCS, NCBCS, and GBCS cows, MLBCS cows had $(\mathrm{P}<0.001)$ lower somatic cell linear score than NCBCS cows, and NCBCS cows had $(\mathrm{P}<0.001)$ higher somatic cell count than GBCS cows. Cows 
from dairy A had $(\mathrm{P}<0.001)$ reduced somatic cell linear score compared with cows from dairy B (3.31 \pm 0.03 vs. $3.61 \pm 0.03)$. Additionally, primiparous cows $(\mathrm{P}<0.001)$ had lower somatic cell linear score than multiparous cows $(3.18 \pm 0.03$ vs. $3.74 \pm 0.03)$.

\subsection{DISCUSSION}

The current study was a retrospective observational study. As such, only associations between independent variables and dependent variables are possible. Body condition score change during the dry-period was highly dependent on the BCSD. HAYIRLI et al. (2002) demonstrated that BCS $21 \mathrm{~d}$ prior to the expected calving date explained $9.7 \%$ of the variability in DMI during the prepartum period. The only factors with greater contribution to the variability in DMI in the prepartum period were proximity to calving, NDF of the diet, and parity (HAYIRLI et al., 2002). In the current study, BCSD explained $95 \%$ of the variability in $\triangle \mathrm{BCS}$, granted the model only explained $57.4 \%$ of the variability in $\triangle \mathrm{BCS}$ and several dietary and environmental (e.g. stocking density) factors were not accounted for. HAYIRLI et al. (2002) demonstrated that cows classified as obese $21 \mathrm{~d}$ prior to the expected calving date had lower DMI (as \% of BW) from $21 \mathrm{~d}$ prior to the expected calving date to calving compared with thinner cows. Additionally, the lower in DMI between $21 \mathrm{~d}$ prior to the expected calving date and calving was $40 \%, 29 \%$, and $28 \%$ for obese, moderate, and thin cows, respectively (HAYIRLI et al., 2002). HOEDEMAKER, PRANGE, and GUNDELACH (2009) demonstrated that the BCS of cows that lost more than 0.25 unit of BCS during the last $30 \mathrm{~d}$ of gestation was approximately 3.5 at 6 weeks prepartum, the BCS of cows that lost 0.25 unit of BCS during the last $30 \mathrm{~d}$ of gestation was approximately 3.3 at 6 weeks prepartum, and BCS of cows that maintained or gained BCS during the last $30 \mathrm{~d}$ of gestation was approximately 3.1 at 6 weeks prepartum. In the current study, BCSD $\leq 3.25$ was a good predictor of GBCS during the dryperiod. Additionally, while the differences in BCSD among ELBCS, MLBCS, NCBCS, and GBCS cows averaged 0.26 unit, the differences in BCS at calving among ELBCS, MLBCS, NCBCS, and GBCS cows averaged 0.13 unit. These data suggest that the cows used in this study were genetically programmed to converge to BCS at calving between 3.25 and 3.5. In a review, GARNSWORTHY and WISEMAN (2006) suggested that Holstein cows are genetically programmed to converge to BCS between 2.5 and 3 around 12 weeks postpartum. Heritability of BCS at 0 to 60 DIM, 130 to 170 DIM, and 280 to 320 DIM is approximately 
$0.26 \pm 0.08$ (VALLIMONT et al., 2010), supporting the hypothesis that Holstein cows are programmed to be within ranges of BCS at different stages of gestation and lactation.

Cows that lost BCS during the dry-period were more likely to be diagnosed with uterine diseases and indigestion and were more likely to receive antimicrobial, anti-inflammatory, and supportive therapies. Although the interaction between $\triangle \mathrm{BCS}$ and parity tended to be associated with the likelihood of indigestion, the interaction between $\triangle \mathrm{BCS}$ and dry-period length tended to be associated with the likelihood of treatment with antimicrobial, and the interactions between $\triangle B C S$ and parity and between $\triangle B C S$ and dry-period length tended to be associated with the likelihood of treatment with anti-inflammatories. In general, GBCS cows had better health than NCBCS, MLBCS, and ELBCS cows. HUZZEY et al. (2007) demonstrated that cows diagnosed with metritis postpartum had reduced DMI as early as $13 \mathrm{~d}$ prepartum. HAMMON et al. (2006) demonstrated that cows in the lowest quartile for DMI in the last 3 weeks of gestation had reduced myeloperoxidase activity compared with cows in the highest quartile for DMI. Furthermore, there was a negative correlation between non-esterified fatty acid plasma concentration and neutrophil activity (HAMMON et al., 2006). OSPINA et al. (2010) demonstrated that increased prepartum and postpartum non-esterified fatty acid plasma concentrations were associated with increased risk of retained fetal membranes, metritis, clinical ketosis, and displacement of abomasum. Furthermore, increase in prepartum fat mobilization and serum lipoprotein metabolism was associated with increased risk of metritis and retained fetal membranes (CONTRERAS; RYAN; OVERTON, 2004; KANEENE et al., 1997). The study reported herein was retrospective; thus, it was not possible to determine whether differences in concentrations of metabolites and hormones existed during the prepartum and postpartum according to $\triangle \mathrm{BCS}$. Nonetheless, the amounts of $\triangle \mathrm{BCS}$ from dryoff to calving were $-0.85 \pm 0.16,-0.34 \pm 0.12,0 \pm 0$, and $0.34 \pm 0.17$ for ELBCS, MLBCS, NCBCS, and GBCS, respectively. Therefore, if the BW of the cows in the current study was approximately $700 \mathrm{~kg}$, such $\triangle \mathrm{BCS}$ would represent approximately $-383,-153,0$, and $+181 \mathrm{Mcal}$ of $\mathrm{NE}_{\mathrm{L}}$ during the dry-period for ELBCS, MLBCS, NCBCS, and GBCS cows, respectively (NRC, 2001). It can be speculated that cows that had ELBCS and MLBCS had negative energy balance and, consequently, impaired immune response during the periparturient period, which may have predisposed them to uterine diseases. SMITH et al. (2017) demonstrated that cows diagnosed with uterine diseases and metabolic disorders lost -0.27 and -0.24 unit of BCS from dry-off to calving, respectively, whereas healthy cows lost -0.11 unit of BCS during the same period. The lack of association between $\triangle \mathrm{BCS}$ and metabolic diseases postpartum was somewhat unexpected. Only clinical metabolic diseases were recorded in the current study; 
thus, an association between $\triangle \mathrm{BCS}$ and the likelihood of sub-clinical metabolic diseases may not be disregarded.

In the current study, $\triangle \mathrm{BCS}$ was associated with the likelihood of pregnancy after the first and second postpartum AI. Interestingly, cows that gained BCS during the dry-period were less likely to lose pregnancy between $35 \pm 7$ and $67 \pm 3 \mathrm{~d}$ after the first and second postpartum AI. The associations between $\triangle \mathrm{BCS}$ and reproductive outcomes may be confounded by the increased likelihood of health disorders affecting ELBCS, MLBCS, and NCBCS cows. The occurrence of postpartum diseases such as dystocia and uterine diseases are associated with postponed resumption of ovarian cycles postpartum, reduced pregnancy per AI, and increased pregnancy loss (LEBLANC et al., 2002; RIBEIRO et al., 2013; RIBEIRO et al., 2016; SANTOS; RUTIGLIANO; SÁ FILHO, 2009). When cows diagnosed with any of the postpartum diseases evaluated in the current study were removed from the analysis, however, differences in pregnancy per AI at $35 \pm 7$ and $67 \pm 3 \mathrm{~d}$ after the first and second postpartum AI and pregnancy loss between $35 \pm 7$ and $67 \pm 3 \mathrm{~d}$ after the first and second postpartum AI were still observed (data not shown). Holstein cows in Germany that lost 0.25 or more than 0.25 unit of BCS during the last 6 weeks of gestation were less likely to conceive after the first postpartum AI, were less likely to be pregnant by 200 DIM, and had longer interval from calving to conception compared with cows that had no change or gained BCS during the last 6 weeks of gestation (HOEDEMAKER; PRANGE; GUNDELACH, 2009). In an experiment conducted in New York, researchers demonstrated that loss of BCS during the dry-period was associated with greater risk of dystocia, culling, and reproductive failure (GEARHART et al., 1990). Although DOMECQ et al. (1997a) did not observe an association between $\triangle \mathrm{BCS}$ during the dry period and conception to the first postpartum AI, they did not report the long-term effects of $\triangle \mathrm{BCS}$ on reproductive performance. SHEEHY et al. (2017) demonstrated that cows that lost BCS during the last $15 \mathrm{~d}$ of gestation tended to have greater non-esterified fatty acid concentrations and had reduced insulin concentrations during the prepartum compared with cows that maintained BCS, whereas during the postpartum period cows that lost BCS during the last $15 \mathrm{~d}$ of gestation had greater non-esterified fatty acid and BHB concentrations and reduced insulin concentration compared with cows that maintained BCS. CHEN et al. (2015) demonstrated that cows that resumed ovarian cycles before 21 DIM had greater BCS from 1 to 8 weeks postpartum. Additionally, cows with normal ovarian cycles (18-24 days) had greater concentrations of insulin and IGF-1 from 1 to 8 weeks postpartum (CHEN et al., 2015). As explained previously, the study reported herein is a retrospective analysis of the factors associated with $\triangle \mathrm{BCS}$ and the consequences of $\triangle \mathrm{BCS}$ to performance. Nonetheless, it is reasonable to speculate that cows 
with excessive BCS loss during the prepartum period had altered metabolites and hormones concentrations as described by CHEN et al. (2015) and SHEEBY et al. (2017), which may have led to impaired reproductive performance.

Cows that gained BCS during the dry-period had greater yield of milk, fat, protein, and $3.5 \%$-FCM than cows that maintained BCS and cows that lost BCS during the dry-period. Compared with GBCS cows, ELBCS, MLBCS, and NCBCS cows produced in average 4.17, 2.34, and 1.59 fewer $\mathrm{kg} / \mathrm{d}$ of milk, respectively, and 4.0, 2.15, and 1.66 fewer $\mathrm{kg} / \mathrm{d}$ of 3.5\%FCM, respectively, in the first month postpartum. Differences in yield of milk and 3.5\%-FCM over the entire lactation, however, were smaller. This suggests that cows that gained BCS during the dry-period were actually better able to cope with the demands of onset of lactation. DOMECQ et al. (1997b) demonstrated that a 1-unit increment in BCS during the dry-period resulted in increased milk yield of $0.32 \mathrm{~kg} / \mathrm{d}$ among multiparous cows. Nutrient requirements of pregnant cows increase significantly in the last weeks of gestation (MOE; TYRRELL, 1972) and DMI decreases in the last days of gestation resulting in slight negative energy balance during the last days prior to parturition (BERTICS et al., 1992). Cows that gained BCS during the dry-period would have more positive energy balance in the last $60 \mathrm{~d}$ of gestation than cows with NCBCS, MLBCS and ELBCS, which may have resulted in more energy reserves at the onset of lactation for higher yields of milk, fat, and protein. Although the reduced incidence of health disorders and treatments among GBCS cows may suggest a confounding effect of health disorders on the association between $\triangle \mathrm{BCS}$ and productive parameters, when cows that had any of the health disorders evaluated in the current study were removed from the analysis similar differences in productive parameters were still observed among GBCS, NCBCS, MLBCS, and ELBCS cows (data not shown). It is surprising that GBCS cows had significantly better pregnancy per AI following the first and second postpartum inseminations compared with NCBCS, MLBCS, and ELBCS cows while still producing significantly more milk, fat, and protein early postpartum. This leads to the conclusion that prevention of BCS loss in the dryperiod is critical for the success of the subsequent lactation, whereas the importance of BCS at calving must be evaluated in light of the $\triangle \mathrm{BCS}$.

The association between $\triangle \mathrm{BCS}$ and somatic cell count is interesting and reinforces the speculation that cows that lost BCS during the dry-period may have had impaired innate immunity reducing the cow's ability to resolve pre-existing intra-mammary infections and prevent new intra-mammary infections during the dry-period. It is particularly striking that ELBCS cows had reduced somatic cell linear score before dry-off than all other cows, but postpartum ELBCS cows tended to have and had greater somatic cell linear score than NCBCS 
and GBCS cows, respectively. VALDE et al. (2007) reported that in herds with greater incidence of mastitis cows had greater BCS during the dry-period than herds with lower incidence of mastitis, but by the second month of lactation BCS did not differ. LEELAHAPONGSATHON et al. (2016) demonstrated that greater BCS during the dry period and reduced BCS at calving were predisposing factors to intra-mammary infection. As discussed previously, reduced DM intake during the prepartum was associated with reduced myeloperoxidase activity (HAMMON et al., 2006) and increased concentrations of non-esterified fatty acid plasma concentration were associated with reduced neutrophil activity (HAMMON et al., 2006) and increased risk of retained fetal membranes, metritis, clinical ketosis, and displacement of abomasum (OSPINA et al., 2010). Prevention of BCS loss during the dry-period may have a positive impact on udder health and incidence of mastitis postpartum. 


\section{REFERENCES}

AKERS, R. M. Endocrine, growth factor, and neural regulation of mammary development. In: AKERS, R. M. Lactation and the mammary gland. Ames, IA: Blackwell Publishing Professional, 2002. p. 165-198.

BAUMAN, D. E. Regulation of nutrient partitioning during lactation: homeostasis and homeorhesis revisited. In: CRONJÉ, P. H. (Ed.). Ruminant physiology: digestion, metabolism, growth, and reproduction. Cambridge, MA: CABI Publishing, 2000. p. 311-328.

BAUMAN, D. E.; CURRIE, W. B. Partitioning of nutrients during pregnancy and lactation: a review of mechanisms involving homeostasis and homeorhesis. Journal Dairy Science, v. 63, p. 1514-1529, 1980.

BERTICS, S. J.; GRUMMER, R. R.; CADORNIGA-VALINO, C.; STODDARD, E. E. Effect of prepartum dry matter intake on liver triglyceride concentration and early lactation. Journal Dairy Science, v. 75, p. 1914-1922, 1992.

BURTON, J. L.; KEHRLI JR, M. E. Regulation of neutrophil adhesion molecules, and shedding of Staphylococcus aureus in milk of cortisol- and dexamethasone-treated cows. American Journal of Veterinary Research, v. 56, p. 997-1006, 1995.

BURTON, J. L. et al. Regulation of L-selectin and CD18 on bovine neutrophils by glucocorticoids: effects of cortisol and dexamethasone. Journal of Leukocyte Biology, v. 57, p. 317-325, 1995.

BURTON, J. L. et al. Gene expression signatures in neutrophils exposed to glucocorticoids: A new paradigm to help explain "neutrophil dysfunction" in parturient dairy cows. Veterinary Immunology and Immunopathology, v. 105, p. 197-219, 2005.

CARDOSO, F. C. et al. Prepartum nutritional strategy affects reproductive performance in dairy cows. Journal Dairy Science, v. 96, p. 5859-5871, 2013.

CHEN, J. et al. Relationship between metabolism and ovarian activity in dairy cows with different dry-period lengths. Theriogenology, v. 84, p. 1387-1396, 2015.

CONTRERAS, L. L.; RYAN, C. M.; OVERTON, T. R. Effects of dry cow grouping strategy and prepartum body condition score on performance and health of transition dairy cows. Journal Dairy Science, v. 87, p. 517-523, 2004.

CORREA, M. T.; ERB, H.; SCARLETT, J. Path analysis for seven postpartum disorders of Holstein cows. Journal Dairy Science, v. 76, p. 1305-1312, 1993. 
CROOKENDEN, M. A. et al. Effects of precalving body condition and prepartum feeding level on gene expression in circulating neutrophils. Journal Dairy Science, v. 100, p. 2310-2322, 2016.

DOMECQ, J. J. et al. Relationship between body condition scores and conception at first artificial insemination in a large dairy herd of high yielding Holstein cows. Journal Dairy Science, v. 80, p. 113-120, 1997a.

DOMECQ, J. J. et al. Relationship between body condition scores and milk yield in a large dairy herd of high yielding Holstein cows. Journal Dairy Science, v. 80, p. 101-112, 1997b.

ERB, H. N.; GROHN, Y. T. Symposium: health problems in the periparturient cow. Epidemiology of metabolic disorders in the periparturient dairy cow. Journal Dairy Science, v. 71, p. 2557-2571, 1988.

FERGUSON, J. D.; GALLIGAN, D. T.; THOMSEN, N. Principal descriptors of body condition score in Holstein cows. Journal Dairy Science, v. 77, p. 2695-26703, 1994.

GARNSWORTHY, P. C.; WISEMAN, J. Body condition score in dairy cows: targets for production and fertility. In: RECENT advances in animal nutrition. Nottingham: Nottingham University Press, 2006. p. 61-86.

GEARHART, M. A. et al. Relationship of changes in condition score to cow health in Holsteins. Journal Dairy Science, v. 73, p. 3132-3140, 1990.

GROHN, Y. T. et al. Epidemiology of metabolic disorders in dairy cattle: association among host characteristics, disease, and production. Journal Dairy Science, v. 72, p. 1876-1885, 1989.

GRUMMER, R. R.; MASHEK, D. G.; HAYIRLI, A. Dry matter intake and energy balance in the transition period. Veterinary Clinics of North America Food Animal Practice, v. 20, p. 447-470, 2004.

HAMMON, D. S. et al. Neutrophil function and energy status in Holstein cows with uterine health disorders. Veterinary Immunology and Immunopathology, v. 113, p. 21-29, 2006.

HAYIRLI, A. et al. Animal and dietary factors affecting feed intake during the prefresh transition period in Holsteins. Journal Dairy Science, v. 85, p. 3430-3443, 2002.

HILL, A. W.; REID, I. M.; COLLINS, R. A. Influence of liver fat on experimental Escherichia coli mastitis in periparturient cows. Veterinary Record, v. 117, p. 549-551, 1985. 
HOEDEMAKER, M.; PRANGE, D.; GUNDELACH, Y. Body condition change ante- and postpartum, health and reproductive performance in German Holstein cows. Reproduction in Domestic Animals, v. 44, p. 167-173, 2009.

HUZZEY, J. M. et al. Prepartum behavior and dry matter intake identify dairy cows at risk for metritis. Journal Dairy Science, v. 90, p. 3220-3233, 2007.

IBANEZ, L. et al. Neutrophil count in small-for-gestational age children: Contrasting effects of metformin and growth hormone therapy. Jornal of Clinical Endocrinology and Metabolism, v. 90, p. 3435-3439, 2005.

INOUE, T. et al. Growth hormone and insulin-like growth factor I augment bactericidal capacity of human polymorphonuclear neutrophils. Shock, v. 10, p. 278-284, 1998.

KADIVAR, A.; AHMADI, M. R.; VATANKHAH, M. Associations of prepartum body condition score with occurrence of clinical endometritis and resumption of postpartum ovarian activity in dairy cattle. Tropical Animal Health and Production, v. 46, p. 121-126, 2014.

KANEENE, J. B. et al. The association of serum nonesterified fatty acids and cholesterol, management and feeding practices with peripartum disease in dairy cows. Preventive Veterinary Medicine, v. 31, p. 59-72, 1997.

KIMATA, H., YOSHIDA, A. Differential effect of growth hormone and insulin-like growth factor-I, insulin-like growth factor-II, and insulin on Ig production and growth in human plasma cells. Blood, v. 83, p. 1569-1574, 1994.

KIMURA, K.; GOFF, J. P.; KEHRLI JR., M. E. Effects of the presence of the mammary gland on expression of neutrophil adhesion molecules and myeloperoxidase activity in periparturient dairy cows. Journal Dairy Science, v. 82, p. 2385-2392, 1999.

KLUCINSKI, W. et al. Effect of ketone bodies on the phagocytic activity of bovine milk macrophages and polymorphonuclear leukocytes. Z. Veterinärmed, v. 35, p. 632-639, 1988.

KOJIMA, C. J. et al. Physiological and immunological responses to weaning and transport in the young pig: Modulation by administration of porcine somatotropin. Journal of Animal Science, v. 86, p. 2913-2919, 2008.

LEBLANC, S. J. et al. Defining and diagnosing postpartum clinical endometritis and its impact on reproductive performance in dairy cows. Journal Dairy Science, v. 85, p. 2223-2236, 2002.

LEELAHAPONGSATHON, K. et al. Factors in dry period associated with intramammary infection and subsequent clinical mastitis in early postpartum cows. Asian Australas. Journal 
of Animal Science, v. 29, p. 580-585, 2016.

LUCY, M. C. Functional differences in the growth hormone and insulin-like growth factor axis in cattle and pigs: implications for post-partum nutrition and reproduction. Reproduction in Domestic Animals, v. 43, p. 31-39, 2008.

MCCARTHY, S. D. et al. Differences in the expression of genes involved in the somatotropic axis in divergent strains of Holstein-Friesian dairy cows during early and mid lactation. Journal Dairy Science, v. 92, p. 5229-5238, 2009.

MOE, P. W.; TYRRELL, H. F. Metabolizable energy requirements of pregnant dairy cows. Journal Dairy Science, v. 55, p. 480-483, 1972.

NANDA, A. S.; DOBSON, H.; WARD, W. R. Relationship between an increase in plasma cortisol during transport-induced stress and failure of oestradiol to induce a luteinising hormone surge in dairy cows. Research in Veterinary Science, v. 49, p. 25-28, 1990.

NRC. NATIONAL RESEARCH COUNCIL. Energy requirement of lactating and pregnant cows, p. 13-27, 2001. Nutrient Requirements of Dairy Cattle. 7th ed. Natl. Acad. Press, Washington, DC, USA.

OSPINA, P. A. et al. Evaluation of nonesterified fatty acids and $\beta$-hydroxybutyrate in transition dairy cattle in the northeastern United States: Critical thresholds for prediction of clinical diseases. Journal Dairy Science, v. 93, p. 546-554, 2010.

REIST, M. et al. Use of threshold serum and milk ketone concentrations to identify risk for ketosis and endometritis in high-yielding dairy cows. AJVR, v. 64, p. 188-194, 2003.

RHOADS, R. P. et al. Insulin increases the abundance of the growth hormone receptor in liver and adipose tissue of periparturient dairy cows. Journal of Nutrition, v. 134, p. 1020-1027, 2004.

RIBEIRO, E. S. et al. Prevalence of periparturient diseases and effects on fertility of seasonally calving grazing dairy cows supplemented with concentrates. Journal Dairy Science, v. 96, p. 5682-5697, 2013.

RIBEIRO, E. S. et al. Carryover effect of postpartum inflammatory diseases on developmental biology and fertility in lactating dairy cows. Journal Dairy Science, v. 99, p. 2201-2220, 2016.

ROCHE, J. R. et al. Invited review: Body condition score and its association with dairy cow productivity, health, and welfare. Journal Dairy Science, v. 92, p. 5769-5801, 2009. 
RUKKWAMSUK, T.; KRUIP, T. A.; WENSING, T. Relationship between overfeeding and over conditioning in the dry period and the problems of high producing dairy cows during the postparturient period. Veterinary Quarterly, v. 21, p. 71-77, 1999.

SANDER, A. K. et al. Ex vivo phagocytic overall performance of neutrophilic granulocytes and the relation to plasma insulin-like growth factor-I concentrations in dairy cows during the transition period. Journal Dairy Science, v. 94, p. 1762-1771, 2011.

SANTOS, J. E.; RUTIGLIANO, H. M.; SÁ FILHO, M. F. Risk factors for resumption of postpartum estrous cycles and embryonic survival in lactating dairy cows. Animal Reproduction Science, v. 110, p. 207-221, 2009.

SHEEHY, M. R. et al. A comparison of serum metabolic and production profiles of dairy cows that maintained or lost body condition 15 days before calving. Journal Dairy Science, v. 100, p. 536-547, 2017.

SMITH, G. L. et al. Association between body energy content in the dry period and post-calving production disease status in dairy cattle. Animal, v. 11, p. 1590-1598, 2017.

SOHMIYA, M.; KANAZAWA, I.; KATO, Y. Effect of recombinant human GH on circulating granulocyte colony-stimulating factor and neutrophils in patients with adult GH deficiency. European Journal of Endocrinology, v. 152, p. 211-215, 2005.

STEVENSON, J. S. Clinical reproductive physiology of the cow. In: Youngquist, R. S.; Threlfall, W. R (Ed.). Current Therapy in Large Animal Theriogenology, 2. ed. Saint Louis, MO: Saunders Elsevier, 2007. p. 259-270

VALDE, J. P. et al. Comparison of feeding management and body condition of dairy cows in herds with low and high mastitis rates. Journal Dairy Science, v. 90, p. 4317-4324, 2007.

VALLIMONT, J. E. et al. Genetic parameters of feed intake, production, body weight, body condition score, and selected type traits of Holstein cows in commercial tie-stall barns. Journal Dairy Science, v. 93, p. 4892-4901, 2010.

VIEIRA-NETO, A. et al. Association among gestation length and health, production, and reproduction in Holstein cows and implications for their offspring. Journal Dairy Science, v. 100, p. 3166-3181, 2017.

WATHES, D. C. et al. Negative energy balance alters global gene expression and immune responses in the uterus of postpartum dairy cows. Physiological Genomics, v. 39, p. 1-13, 2009. 


\section{GENERAL CONCLUSIONS}

The current study is retrospective and, consequently, no cause and effect may be established. Loss of BCS during the dry-period was associated with negative health, reproductive, and productive performances. This is an important finding because it reinforces the perception that a successful lactation starts during the dry-period. Subpar management and environmental conditions that prevent BCS gain in the dry-period must be avoided at all costs. Of particular importance to prevent BCS loss during the dry-period is to assure that cows are dried-off with $\mathrm{BCS} \leq 3.25$, which is attainable by proper genetic selection of dairy cattle, high milk yield and efficient reproductive management. 


\section{PRACTICAL IMPLICATIONS}

A vicious cycle is established when productive and reproductive performances are subpar in dairy operations. Cows that produce little milk and have prolonged interval from calving to pregnancy establishement are at increased risk of having high BCS at dry-off. Elevated BCS at dry-off is a major predisposing factor for BCS loss during the prepartum period and, as demonstrated in this study, BCS loss during the prepartum period is associated with increased risk of uterine diseases and indigestion, increased risk of treatment with antimicrobial and antiinflammatory drugs, reduced milk yield, and reduced reproductive performance. No singular aspect of management dictates whether or not cows will maitain high production and have short interval from calving to pregnancy establishement. Among them are genetics, proper nutrition and water availability, heat stress abatement pre- and post-partum, reduced incidence of diseases (metabolic, infectious, and lameness), reduced stress (stocking density, proper handling), aggressive reproductive management to assure high insemination rates, use of good quality semen from bulls with greater calving ease, and proper age and body size at first calving to cite a few. Common characteristics among managers of the dairies with the best productive and reproductive performances are the understanding of the multi-faceted nature of success and the need for constant and stable management. 